\title{
Onderwijsarbeidsmarkt en lerarenopleidingen op Caribisch Nederland
}

Citation for published version (APA):

Cörvers, F., Claessen, J., \& Kluijfhout, E. (2015). Onderwijsarbeidsmarkt en lerarenopleidingen op

Caribisch Nederland. ROA. ROA Technical Reports No. 002 https://doi.org/10.26481/umarot.2015002

Document status and date:

Published: 01/01/2015

DOI:

10.26481/umarot.2015002

\section{Please check the document version of this publication:}

- A submitted manuscript is the version of the article upon submission and before peer-review. There can be important differences between the submitted version and the official published version of record.

People interested in the research are advised to contact the author for the final version of the publication, or visit the DOI to the publisher's website.

- The final author version and the galley proof are versions of the publication after peer review.

- The final published version features the final layout of the paper including the volume, issue and page numbers.

Link to publication

\footnotetext{
General rights rights.

- You may freely distribute the URL identifying the publication in the public portal. please follow below link for the End User Agreement:

www.umlib.nl/taverne-license

Take down policy

If you believe that this document breaches copyright please contact us at:

repository@maastrichtuniversity.nl

providing details and we will investigate your claim.
}

Copyright and moral rights for the publications made accessible in the public portal are retained by the authors and/or other copyright owners and it is a condition of accessing publications that users recognise and abide by the legal requirements associated with these

- Users may download and print one copy of any publication from the public portal for the purpose of private study or research.

- You may not further distribute the material or use it for any profit-making activity or commercial gain

If the publication is distributed under the terms of Article $25 \mathrm{fa}$ of the Dutch Copyright Act, indicated by the "Taverne" license above, 


\title{
Vooronderzoek
}

\section{Onderwijsarbeidsmarkt en lerarenopleidingen op Caribisch Nederland}

\author{
Frank Cörvers (ROA) \\ Jos Claessen (OU) \\ Erik Kluijfhout (OU)
}

\section{ROA Technical Report}

ROA-TR-2015/2

Researchcentrum voor Onderwijs en Arbeidsmarkt | ROA

Research Centre for Education and the Labour Market | ROA 


\section{Vooronderzoek}

\section{Onderwijsarbeidsmarkt en lerarenopleidingen op Caribisch Nederland}

Frank Cörvers (ROA)

Jos Claessen (OU)

Erik Kluijfhout (OU)

ROA-TR-2015/2

April 2015

Research Centre for Education and the Labour Market Maastricht University

P.O. Box 616, 6200 MD Maastricht, The Netherlands

$\mathrm{T}+31433883647 \mathrm{~F}+31433884914$

secretary-roa-sbe@maastrichtuniversity.nl

www.roa.nl 


\section{Inhoudsopgave}

Voorwoord

1. Inleiding

1.1 Doelstelling Maestro Kompas

1.2 Blended online onderwijs

1.3 Doel en onderzoeksvragen

1.4 Paragraafindeling

2. Situatieschets 4

2.1 Caribisch Nederland en 10-10-10 4

2.2 Veranderingen in het onderwijs sinds 10-10-10 4

$\begin{array}{lll}2.3 & \text { Kleinschaligheid onderwijs } & 6\end{array}$

2.4 'Governance' problematiek 9

2.5 Arbeidsmarktproblematiek 9

$\begin{array}{lll}2.6 & \text { Sociale problematiek } & 12\end{array}$

2.7 Taalproblematiek 12

3. De arbeidsmarkt voor leraren 13

3.1 Model personeelsbehoefte 13

$\begin{array}{lll}3.2 & \text { Bevolkingsomvang, leerlingenaantallen en scholen } & 14\end{array}$

3.3 Uitbreidings- en vervangingsvraag naar leraren 16

$\begin{array}{lll}3.4 & \text { Herkomst en bevoegdheid van leraren } & 18\end{array}$

$\begin{array}{lll}3.5 & \text { Opleidingsbehoefte onder leraren } & 21\end{array}$

4. Randvoorwaarden en opties voor digitale onderwijsinfrastructuur $\quad 24$

$\begin{array}{lll}4.1 & \text { Randvoorwaarden } & 24\end{array}$

4.2 Status van UniCarib partners bij blended online onderwijs 25

4.3 Componenten van een digitale infrastructuur 28

4.4 Dominante infrastructuurmodellen 29

4.5 Opties voor onderwijsconsortia 31 
5. Conclusies $\quad 33$

5.1 Situatie onderwijs op Caribisch Nederland 33

5.2 Personeelsbehoefte aan leraren $\quad 33$

5.3 Opleidingsbehoefte van leraren 33

5.4 Onderwijsinfrastructuur voor het opleiden en scholen van leraren 34

5.5 Virtuele campus en blended online onderwijsmodel 34

5.6 Toekomstig onderzoek onderwijsarbeidsmarkt voor Caribisch Nederland 35 


\section{Voorwoord}

Dit vooronderzoek is uitgevoerd door het Researchcentrum voor Onderwijs en Arbeidsmarkt (ROA) en de Open Universiteit (OU) in opdracht van Maestro Kompas. De auteurs danken Wim Didderen (Maestro Kompas) voor het mogelijk maken van het onderzoek. Voorts danken zij Hanneke de Bekker (Inspectie van het Onderwijs), Elisabeth George (Raad Onderwijs Arbeidsmarkt Caribisch Nederland), Lian Kösters (Centraal Bureau voor de Statistiek), Jan Willem Maijvis (Inspectie van het Onderwijs), Lisette Vels (Dienst Uitvoering Onderwijs) voor het aanleveren van de benodigde databestanden en overige gegevens. 


\section{Inleiding}

\subsection{Doelstelling Maestro Kompas}

Ter verbetering van het aanbod van goed opgeleide leraren op Caribisch Nederland (CN) is door het ministerie van OCW het programma Maestro Kompas in het leven geroepen. Het betreft hier in hoofdzaak leraren die op de zogenoemde BES-eilanden (Bonaire, Sint Eustatius, Saba) in het primair onderwijs (po), het voortgezet onderwijs (vo) en het middelbaar beroepsonderwijs (mbo) werkzaam zijn. De doelstelling van Maestro Kompas is tweeledig:

1. Het opleiden van on(der)bevoegde leraren op Caribisch Nederland.

2. Het opzetten van een duurzame regionale onderwijsinfrastructuur, waarbij virtuele leeromgevingen een belangrijke rol spelen.

De Hogeschool Utrecht/Faculteit Educatie (HU/FE) en de Open Universiteit (OU) geven binnen het programma van Maestro Kompas trainingen voor onbevoegde en onderbevoegde leraren. Daardoor kunnen deze leraren zich verder bekwamen en/of alsnog hun bevoegdheid halen. Dit is van belang om op de korte termijn het niveau van het onderwijs op de BES-eilanden te verbeteren. Met het oog op de middellange termijn wordt met de universiteiten van Curaçao, Aruba en Sint Maarten en de lerarenopleiding van Aruba samengewerkt om een duurzame regionale onderwijsinfrastructuur op te zetten. Hierachter ligt het streven dat het bekwamen en opleiden van leraren volledig in de eigen regio wordt georganiseerd. Leraren zouden dus in de toekomst in hun eigen praktijkomgeving moeten kunnen leren.

Gericht op een duurzame samenwerking tussen de verschillende onderwijsinstellingen voor lerarenopleidingen is op 20 maart 2014 de raamovereenkomst UniCarib getekend door de universiteiten van Sint Maarten, Curacao en Aruba, en het Instituto Pedagogico Arubano (IPA). UniCarib is mede tot stand gekomen op initiatief van Maestro Kompas. Doel van het samenwerkingsverband is om het onderwijs en onderzoek in de Caribische regio, in de breedst mogelijke zin, te versterken. Meer in het bijzonder gaat het om het opzetten van een duurzame (digitale) onderwijsinfrastructuur in de Caribische regio door de partners binnen UniCarib. Dit moeten leiden tot een structurele verbetering van het niveau van professionalisering van de scholen en de onderwijsgevenden op Bonaire, Sint Eustatius en Saba. De professionalisering omvat (bij)scholing van onderwijsgevenden, kwaliteitsbevordering van lerarenopleiders, en wetenschappelijk onderzoek naar ontwikkelingen op dit gebied. Daarnaast heeft UniCarib de ambitie om als consortium ook andere onderwijsmarkten te verkennen, zowel inhoudelijk (i.e. buiten professionalisering) als geografisch (i.e. buiten BES-eilanden in Caribisch gebied). In het licht daarvan kunnen er in de toekomst nieuwe partners toetreden tot UniCarib, of kan er worden samengewerkt met andere (onderwijs)instellingen. 


\subsection{Blended online onderwijs}

De Unicarib partners, de scholen, docenten en studenten zijn verspreid over een uitgestrekte regio. Het fysiek bij elkaar brengen van studenten en docenten is kostbaar in termen van tijd (reistijd) en geld (vervoer, verblijfskosten). Daarnaast bestaat een belangrijk deel van de doelgroep uit drukbezette werkende professionals waarvoor het belangrijk is om zelf te kunnen bepalen waar en wanneer ze willen studeren (plaats- en tijds-onafhankelijk). Toch is het nuttig studenten ook onderling met elkaar in contact te brengen (voor bijvoorbeeld delen van ervaringen, samenwerken aan opdrachten, peer-support), zeker voor locaties met geïsoleerde of kleine aantallen studenten.

Een mogelijke oplossing voor de geschetste situatie op Caribisch Nederland is een online (beschikbaar via internet) leeromgeving waarbinnen niet alleen lesmateriaal wordt aangeboden, maar die ook uitgebreide communicatie- en samenwerkingsmogelijkheden 'op afstand' biedt. Een dergelijke online leeromgeving biedt daarnaast docenten de mogelijkheid om onderling eenvoudig lesmateriaal te delen, eventueel lessen van elkaar over te nemen, en om gastdocenten in te zetten.

Daarnaast wordt er vanuit gegaan dat bijvoorbeeld vaardighedentraining en het geven van directe feedback nodig blijven, zodat studenten en docenten elkaar fysiek dienen te ontmoeten. Dit kan ook het geval zijn bij de introductie en de afsluiting van een vak. Daarbij lijkt het 'blended' maken van lerarenopleidingen een geschikte oplossing. Zo worden er, op initiatief van Maestro Kompas, trainingen gegeven om de PABO-opleiding voor Sint Eustasius (verzorgd door IPA) en de Masteropleidingen Talen (verzorgd door de Universiteit van Curaçao voor Aruba, Bonaire en Curaçao) 'blended' te maken.

Bij efficiënt en effectief blended online onderwijs gaat het dan ook om een mix van:

1. Onderwijs-componenten die zelfstandig door middel van zelfstudie bestudeerd worden;

2. Componenten die via online onderwijzen aangeboden worden;

3. Componenten die tijdens fysieke (groeps)bijeenkomsten worden behandeld.

Een toekomstige virtuele campus zou een dergelijk model van blended online onderwijs moeten ondersteunen.

\subsection{Doel en onderzoeksvragen}

Het doel van dit vooronderzoek is om na te gaan:

- Hoe de onderwijsarbeidsmarkt op CN er nu uitziet wat betreft omvang, samenstelling en dynamiek van de leraren, scholen en lerarenopleidingen;

- Hoe gegeven de kenmerken van de huidige onderwijsarbeidsmarkt, een duurzame regionale onderwijsinfrastructuur met blended online onderwijs opgezet kan worden. 
Hiertoe zijn de volgende onderzoeksvragen geformuleerd:

\section{Wat is de omvang en de samenstelling van de lerarenpopulatie op de verschillende scholen op CN?}

Er wordt hierbij gekeken naar de BES-eilanden totaal en afzonderlijk. Aan de hand van een factsheet moet duidelijk worden hoeveel leraren er zijn en wat hun karakteristieken zijn wat betreft onder meer opleiding, bevoegdheid, bekwaamheid, herkomst, uitstroom, instroom, etc.

\section{Wat zijn de verwachtingen op $\mathrm{CN}$ ten aanzien van de personeelsbehoefte en vacature-invulling van leraren voor de toekomst, zowel in kwantiteit als kwaliteit?}

Het gaat hierbij om een inschatting van de ontwikkeling van het aantal leerlingen op scholen en de vervangingsbehoefte door vertrek en evt. pensionering van leraren.

\section{Wat is hun mogelijke opleidingsbehoefte?}

Het gaat hier om inschatting van de cursussen en trainingen die leraren nu en in de toekomst zouden willen/moeten volgen op hun kennis- en vaardigheidsniveau op peil te houden. Hierbij dient ook rekening te worden gehouden met de (mogelijke toekomstige) richtlijnen van de Onderwijsinspectie ten aanzien van bevoegdheden en bekwaamheden.

\section{Welke rol spelen hierbij tot nu toe IPA, de Hogeschool Utrecht en de Universiteiten van Aruba en Curaçao?}

Hierbij wordt de stand van zaken geschetst bij het opleiden van leraren en het verzorgen van trainingen voor leraren op de BES-eilanden, vooral wat betreft de rol van de genoemde onderwijsinstellingen.

\section{Welke rol kan een virtuele campus (als duurzame onderwijsinfrastructuur) spelen voor $\mathrm{CN}$ en de hele Caribische regio, mede gelet op het samenwerkingsverband UniCarib?}

Bij de beantwoording van deze vraag moet er enige richting worden gegeven aan de opzet van een virtuele campus met blended learning en virtuele leeromgeving, en op welke wijze de partners binnen een dergelijke campus met elkaar samenwerken.

\subsection{Paragraafindeling}

Dit vooronderzoek is gebaseerd op desk research, waar nodig aangevuld met informatie van diverse contactpersonen. Er wordt gebruik gemaakt van gegevens van de Inspectie van het Onderwijs, het CBS en DUO. In paragraaf 2 wordt een situatieschets gegeven van de drie eilanden van Caribisch Nederland betreffende de staatsinrichting, de bevolking en het onderwijs. In paragraaf 3 komen de bovengenoemde eerste drie onderzoeksvragen aan de orde. In paragraaf 4 worden de laatste twee onderzoeksvragen behandeld. In paragraaf 5 volgen de conclusies. 


\section{Situatieschets}

\subsection{Caribisch Nederland en 10-10-10}

Caribisch Nederland is de benaming van de Nederlandse eilanden Bonaire, Sint Eustatius en Saba in de Caribische zee, die sinds 10 oktober 2010 als drie bijzondere gemeenten deel uitmaken van Nederland. Tot die datum waren deze eilanden onderdeel van de Nederlandse Antillen. De wijziging was onderdeel van staatkundige hervormingen binnen het Koninkrijk der Nederlanden. Door de wijziging hield de Nederlandse Antillen op te bestaan, en kregen de andere drie eilanden van de Nederlandse Antillen (Curaçao, Aruba en Sint Maarten) naast Nederland de status van een land binnen het Koninkrijk. Bonaire, Sint Eustatius en Saba staan bekend als BES-eilanden. De drie andere eilanden (Curaçao, Aruba en Sint Maarten) hebben de verzamelnaam CAS-eilanden.

Wie inzoomt op de BES-eilanden zal snel beseffen dat invoering van het Nederlandse onderwijsregime verre van eenvoudig is. Los van de geografische kloof tussen Nederland en de BESeilanden kennen de eilanden onderling ook grote culturele, historische, economische en geografische verschillen. In tabel 2.1 worden enkele kenmerken van de BES-eilanden weergegeven.

Tabel 2.1

Enkele kenmerken van de BES-eilanden

\begin{tabular}{|c|c|c|c|}
\hline & Bonaire & Sint Eustatius & Saba \\
\hline Oppervlakte (in km²) & 288 & 21 & 13 \\
\hline Inwoneraantal & 18.413 & 4.020 & 1.846 \\
\hline Bevolkingsdichtheid (per $\mathrm{km}^{2}$ ) & 57 & 181 & 152 \\
\hline \multirow[t]{5}{*}{ Religie } & $77 \%$ r.-k. & $27 \%$ methodist & $58 \%$ r.-k. \\
\hline & $16 \%$ overig & $25 \%$ r.-k. & $14 \%$ anglicaans \\
\hline & $7 \%$ geen & $21 \% 7 e$ dags adv. & $22 \%$ overig \\
\hline & & $19 \%$ overig & $5 \%$ geen \\
\hline & & $8 \%$ geen & \\
\hline Voertaal & Papiaments & Engels & Engels \\
\hline Taal & Nederlands & Nederlands & Nederlands \\
\hline \multicolumn{4}{|l|}{ Afstanden in km. } \\
\hline Amsterdam & 7.806 & 6.998 & 6.993 \\
\hline Venezuela & 89 & 900 & 900 \\
\hline Bonaire & & 814 & 816 \\
\hline Sint Eustatius & & & 32 \\
\hline
\end{tabular}

Bron: RCN (2014)

\subsection{Veranderingen in het onderwijs sinds 10-10-10}

Als bijzondere gemeenten vallen de BES-eilanden sinds ' $10-10-10$ ' onder de Nederlandse wet- en regelgeving. Dat geldt ook voor het onderwijs, waardoor de minister van Onderwijs, Cultuur en Wetenschap (OCW) verantwoordelijk is voor het onderwijsbeleid op de BES-eilanden. Dat betekent 
dat de scholen in Caribisch Nederland een regulier onderdeel zijn van het Nederlandse onderwijsstelsel. Voor de overgang naar een Nederlands model is een periode van vijf jaar uitgetrokken. $\mathrm{Er}$ is een fasering voor de invoering van onderwijswetten en voor de financiering van het onderwijs opgesteld. Per 1 januari 2011 worden de BES-scholen rechtstreeks bekostigd vanuit Nederland. Sinds augustus 2011 gelden de (Caribisch) Nederlandse onderwijswetten. Dit betreft de Wet op het primair onderwijs BES (WPO BES), de Wet op het voortgezet onderwijs BES (WVO BES), de Wet educatie en beroepsonderwijs BES (WEB BES), de Wet sociale kanstrajecten jongeren (SKJ $\mathrm{BES}$ ) en de Leerplichtwet BES. De wetten tonen veel gelijkenis met hun pendanten in Europees Nederland. Een aanzienlijk aantal wetsartikelen is niet onmiddellijk van kracht. Ze treden in werking binnen een periode van één tot vijf jaar. Ook de veranderingen ten aanzien van de examens in het voortgezet onderwijs worden geleidelijk ingevoerd.

De gevolgen voor het onderwijs op de BES-eilanden zijn ingrijpend:

- De invoering van de leerplicht vanaf 4 tot en met 16 jaar plus de aanvullende eis van het behalen van een startkwalificatie voor de arbeidsmarkt;

- Funderend onderwijs krijgt de benaming primair onderwijs (po). Scholen in het po zijn vrij om hun instructietaal te kiezen, maar voor alle eilanden zijn er kerndoelen voor de Nederlandse taal gesteld;

- Leerlingen van Bonaire en Sint Eustatius die met het voortgezet onderwijs (vo) starten, worden opgeleid voor de volledig Nederlandstalige examens; op Saba blijft het programma in de Engelse taak in stand. Er wordt voor Sint Eustatius overwogen om het programma in de Engelse taal aan te bieden (zie Faraclas et al., 2013);

- Het secundair beroepsonderwijs wordt middelbaar beroepsonderwijs (mbo);

- Er komt een Expertisecentrum Onderwijszorg (EOZ) om kinderen te begeleiden die extra aandacht nodig hebben;

- De scholen vallen onder het toezicht van de Nederlandse Inspectie voor het Onderwijs (Inspectie van het Onderwijs, 2008; 2014);

- Onderwijsgevenden moeten bevoegd zijn conform de Nederlandse regelgeving;

- De kwaliteit van eventuele opleidingen voor onderwijsgevenden is onderworpen aan het oordeel van de Nederlands Vlaamse Accreditatie Organisatie (NVAO);

- Scholen moeten een uniforme leerlingenregistratie invoeren, alsmede een nieuw volgsysteem, en worden geconfronteerd met de lumpsumfinanciering, het opstellen van een (meerjaren)begroting, een jaarverslag en een jaarrekening naar Europees Nederlands model (Inspectie van het Onderwijs, 2014). Al deze veranderingen verhogen uiteraard de administratieve lastendruk voor de doorgaans relatief kleine scholen op de BES-eilanden (zie hieronder).

In 2008 is het onderwijs op de BES-eilanden de maat genomen door de Nederlandse Inspectie van het Onderwijs (2008). De Onderwijsinspectie hanteerde daarbij haar eigen (Nederlandse) indicatoren (leerstofaanbod / onderwijstijd / pedagogisch-didactisch handelen / schoolklimaat / leerprestaties / zorg en begeleiding / kwaliteitszorg). Per eiland zijn alle scholen bezocht. Per school is er inhoudelijk gerapporteerd, maar informatie over aantallen leerlingen en leraren ontbreekt daarbij. De algehele situatie is zorgelijk: "geen enkele door de overheid bekostigde school op Bonaire en Sint Eustatius levert basiskwaliteit; noch in het funderend, noch in het voortgezet onderwijs. De Sabaanse school voor funderend onderwijs is een goed georganiseerde en opbrengstgerichte school met onderwijs 
van voldoende niveau. De kwaliteit van de school voor vo blijft hierbij achter". Veel scholen zouden in Nederland het predicaat zeer zwak krijgen. "Een van de grootste problemen van het onderwijssysteem is het gebrek aan betrouwbare onderwijsgegevens en statistische informatie" (blz. 22).

Om het onderwijs op de BES-eilanden op het niveau van de Nederlandse basiskwaliteit te krijgen is in 2011 de Onderwijsagenda voor Caribisch Nederland: samen werken aan kwaliteit (Ministerie van OCW, 2011) opgesteld. Verdeeld over vijf prioriteiten zijn de streefdoelen en uit te voeren acties in detail beschreven, waarbij afgesproken is dat de voortgang periodiek wordt geëvalueerd. In 2013 is de voortgang geëvalueerd (Ministerie van OCW, 2013). Er wordt vastgehouden aan de ambities van basiskwaliteit in 2016. De vijf prioriteiten in de Onderwijsagenda zijn:

- Onderwijskwaliteit omhoog, waarbij de taalproblematiek bijzonder aandachtspunt is;

- Versterken kwaliteit van leraren, schoolleiding en schoolbesturen. Er zijn actieplannen voor professionalisering en voor volwaardige lerarenopleidingen;

- Onderwijszorg op maat;

- Aantrekkelijk beroepsonderwijs;

- Randvoorwaarden als administratie / financiën / jaarrekeningen moeten op orde zijn.

In het laatste rapport van de Inspectie van het Onderwijs (2014) wordt geconcludeerd dat er ondanks de weerbarstige situatie met veel inspanningen al veel bereikt is, maar dat er nog een lange weg is te gaan voordat de kwaliteit van het onderwijs in Caribisch Nederland op het Nederlandse niveau in Europa komt. In het primair onderwijs is er een duidelijk trend in de richting van de noodzakelijke basiskwaliteit die in 2016 volgens de afspraken is vereist. De kwaliteitszorg en de begeleiding voor leerlingen die extra ondersteuning nodig hebben blijft achter. Het onderwijs in rekenen en wiskunde is sterk vooruit gegaan, maar voor Nederlands blijft het achter zonder goede vooruitzichten op verbetering (zie ook hieronder bij taalproblematiek). In het voortgezet onderwijs zijn er voor de drie scholen op de BES-eilanden nog flinke inspanningen nodig om de basiskwaliteit in 2016 te halen. Er is vooruitgang geboekt op Bonaire en Saba, maar er is stagnatie op Sint Eustatius zonder duidelijk zicht op verbetering. Ook in het voortgezet onderwijs is er sprake van flinke taalachterstanden onder leerlingen. Het praktijkonderwijs is eveneens onder maat. Het middelbaar beroepsonderwijs lijkt het wat betreft de onderwijskwaliteit beter te doen dan het voortgezet onderwijs, hoewel de kwaliteit van de examinering nog niet volgens de Nederlandse standaarden is. De sociale kanstrajecten voldoen alleen op Bonaire aan de kwaliteitsnormen. De vooruitzichten om hieraan te voldoen zijn op Saba veel beter dan op Sint Eustatius.

\subsection{Kleinschaligheid onderwijs}

Het onderwijs op de drie BES-eilanden is kleinschalig door de geringe bevolkingsomvang. De kleinschaligheid van het onderwijs wordt geillustreerd aan de hand van tabel 2.2, waarin het aantal bekostigde leerlingen per school is weergegeven volgens Dienst Uitvoering Onderwijs (DUO) van het ministerie van OCW. Vooral op Sint Eustatius en Saba zijn de scholen erg klein.

In het primair onderwijs (ро) spelen de verschillende denominaties een belangrijke rol. In de Nederlandse situatie wordt een basisschool met minder dan 200 leerlingen vaak als kleine school beschouwd (Onderwijsraad, 2013). Kleine scholen hebben hogere kosten per leerling, en bovendien 
is er een groter risico op een slechte kwaliteit van het onderwijs. Een leerlingenaantal van 400 à 500 wordt nationaal en internationaal vaak als optimaal gezien. De Onderwijsraad (2013) beschouwt een aantal van 100 leerlingen als een absolute ondergrens vanuit kwaliteitsoogpunt, gebaseerd op de gedachte dat er in die situatie niet meer dan twee leerjaren in 4 combinatieklassen van 25 leerlingen voor 8 leerjaren hoeven te worden samengevoegd. Toch had ca. 20\% van de schoollocaties in 2011 in Nederland minder dan 100 leerlingen (Onderwijsraad, 2013). Zo bezien valt het aantal kleine scholen in het primair onderwijs op de BES-eilanden nog mee, met uitzondering van Sint Eustatius. Daar hebben drie van de vier scholen minder dan 100 leerlingen. In Nederland gelden bij scholen die vanwege hun onderwijskundige visie drie leerjaren combineren (bijvoorbeeld Jenaplanscholen) aanvullende opleidingseisen voor leraren. Op de BES-eilanden komen combinatieklassen echter weinig voor (Inspectie van het Onderwijs, 2014). Dat betekent dat de klassen dus erg klein kunnen zijn, met derhalve hoge kosten per leerling.

Tabel 2.2

Leerlingentelling po, vo en mbo per 1 oktober 2013

\begin{tabular}{|c|c|}
\hline po & \\
\hline Bonaire & \\
\hline Watapana & 49 \\
\hline Luis Beltran & 131 \\
\hline Bon Wardador & 418 \\
\hline Reina Beatrix & 290 \\
\hline Papa Cornes & 401 \\
\hline Pelikaan & 207 \\
\hline San Bernardo & 191 \\
\hline Sint Eustatius & \\
\hline Gov de Graaff & 35 \\
\hline Sevent Day Adv & 93 \\
\hline Golden Rock & 82 \\
\hline Bethel Methodist & 130 \\
\hline Saba & \\
\hline Sacred Heart & 150 \\
\hline Totaal & 2177 \\
\hline vo & \\
\hline Bonaire & \\
\hline Scholengemeenschap Bonaire & 1145 \\
\hline Sint Eustatius & \\
\hline Gwendoline van Putten school & 253 \\
\hline Saba & \\
\hline Saba Comprehensive School & 97 \\
\hline Totaal & 1495 \\
\hline mbo & \\
\hline Bonaire & \\
\hline Scholengemeenschap Bonaire & 505 \\
\hline Sint Eustatius & \\
\hline Gwendoline van Putten school & 39 \\
\hline Saba & \\
\hline Saba Comprehensive School & 21 \\
\hline Totaal & 565 \\
\hline Totaal aantal leerlingen po + vo + mbo & 4237 \\
\hline
\end{tabular}

In het voortgezet onderwijs (vo) en het middelbaar beroepsonderwijs (mbo) wordt het effect van de kleinschaligheid versterkt door de verschillende niveaus en richtingen binnen het onderwijs. In het 
mbo op Bonaire worden er bovendien twee leerwegen aangeboden (bol en deeltijd bbl). Wetenschappelijk onderzoek naar de optimale schoolgrootte in het vo geeft een bandbreedte van 600 tot 1.000 leerlingen aan. Het vo en mbo zijn echter per eiland ondergebracht bij dezelfde school, waardoor dit aantal niet direct te vertalen is naar de BES-eilanden (los van alle andere afwijkende omstandigheden). De Onderwijsraad (2013) concludeert dan ook dat het optimale leerlingenaantal per school en schoolsoort sterk afhangt van de mate van differentiatie in het onderwijsaanbod en de verdeling over de verschillende richtingen. Uit tabel 2.2 blijkt echter dat het aantal leerlingen in het vo op Sint Eustatius en Saba ruim onder het minimum aantal in het vo valt, ook als het mbo wordt meegeteld. Hierdoor zijn de kosten per leerling waarschijnlijk hoger dan gemiddeld, en is er een verhoogd risico op een lager dan gemiddelde onderwijskwaliteit.

Tabel 2.3

Leerlingentelling mbo naar crebo-opleiding, aantal leerlingen per 1 oktober 2013

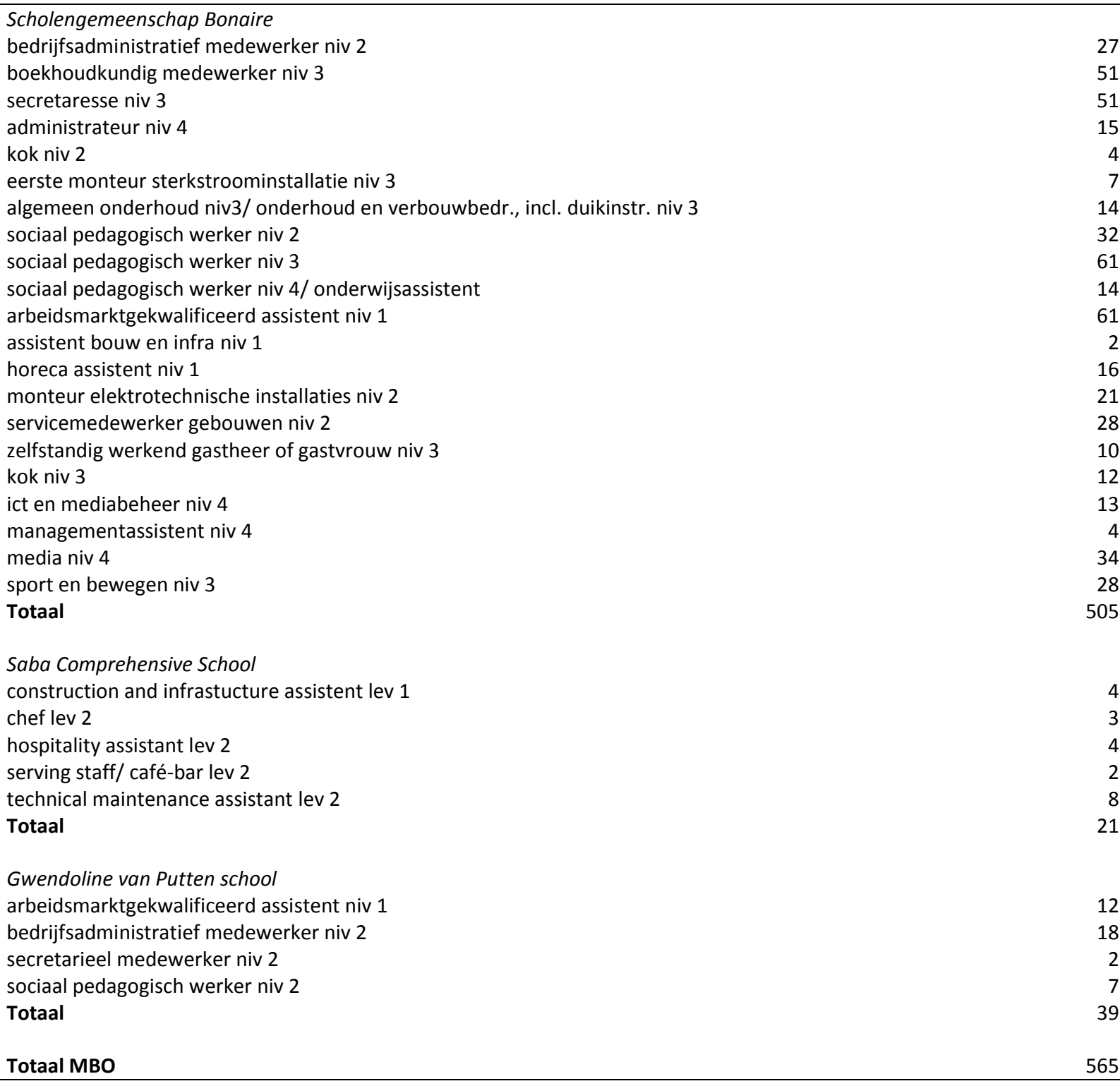

Bron: DUO

In tabel 2.3 is het aantal leerlingen weergegeven per crebo-opleiding. Uit eerder onderzoek van Eimers en Keppel (2014) naar de doelmatigheid van opleidingen in het mbo is gebleken dat een 
gemiddeld aantal van minimaal 18 leerlingen per crebo-opleiding doelmatig is vanuit kostenoptiek in de Nederlandse context. Hoewel ook in Nederland $36 \%$ van de crebo-opleidingen niet aan deze norm voldoet, is dit percentage op de BES-eilanden met $63 \%$ veel hoger. ${ }^{1}$ Dat betekent dat er op de BESeilanden waarschijnlijk hoge kosten worden gemaakt voor het verzorgen van een gedifferentieerd aanbod van mbo-opleidingen.

\section{4 'Governance' problematiek}

De afstand tussen Nederland en de BES-eilanden is gemiddeld 7.200 kilometer; van Bonaire naar Saba en Sint Eustatius is ruim 800 kilometer. Is het inwoneraantal van Bonaire nog te vergelijken met een kleine Nederlandse gemeente, Sint Eustatius en Saba hebben de omvang van een hele kleine deelgemeente. De geringe omvang van de (beroeps)bevolking leidt tot een beperkte bestuurscapaciteit binnen het onderwijs en andere maatschappelijke sectoren. Familierelaties, vrijwilligerswerk, uiteenlopende politieke belangen en verschillen in kerkelijke gezindheid vermengen zich snel met zakelijke en professionele afwegingen in de bestuursfuncties, waarbij ook dubbelfuncties kunnen voorkomen. Vooral op Sint Eustatius en Saba leidt dit gemakkelijk tot inefficiënte en problematische besluitvorming, en staat dit organisatieverbeteringen, het voldoen aan de principes van 'good governance' en een verhoging van de onderwijskwaliteit in de weg (Inspectie van het Onderwijs, 2014). De Inspectie van het Onderwijs (2014) verwacht dat vergaande interventies om de kwaliteit van het bestuur en het onderwijs te verbeteren, inclusief financiële sancties en sluiting van scholen, doordat de beperkte alternatieven op de eilanden weinig effectief zijn. De kleinschaligheid van scholen, zowel in omvang als uniciteit (onderwijstype, denominatie), leidt tot relatief hoge kosten. Dit wordt nog verergerd door transportkosten, doorvoerbelastingen en importheffingen, die niet in de lumpsumbekostiging zijn meegenomen. Complexe regels voor Europese aanbesteding zijn ook van toepassingen op de BES-eilanden. De financiële continuïteit en de bedrijfsvoering lopen vooral op de kleine instellingen aanzienlijke risico's.

\subsection{Arbeidsmarktproblematiek}

De beroepsbevolking op de BES-eilanden wordt gekenmerkt door een grote groep van laagopgeleiden, en door een grote verscheidenheid in herkomst en nationaliteit. In figuur 2.1 wordt het opleidingsniveau van de bevolking tussen 15 en 65 jaar weergegeven op Bonaire, Sint Eustatius, Saba en ter vergelijking Europees Nederland. Uit de figuur blijkt dat op drie eilanden ca. de helft of meer van de bevolking laag is opgeleid (lager dan mbo niveau 2). Op Saba zijn er ten opzichte van Nederland veel hoog opgeleiden (hbo of wo), maar is $48 \%$ laagopgeleid. Ook het aandeel middelbaar opgeleiden (havo/vwo/mbo niv. 2, 3 of 4) is op alle drie de eilanden beduidend lager dan in Nederland.

1. In feite heeft de norm van 18 leerlingen betrekking op een beroep in plaats van een crebo-opleiding. Een beroep behelst in het onderzoek van Eimers en Keppel (2014) een groep van verwante crebo's zonder samenvoeging van niveaus. De crebo-opleidingen die in tabel 3.2 zijn weergegeven kunnen echter als aparte beroepen worden gezien die met de norm van 18 leerlingen mogen worden beoordeeld. 
Figuur 2.1

De bevolking naar opleidingsniveau voor de BES-eilanden (15-65 jr.) en Nederland (15-75 jr.), 2012

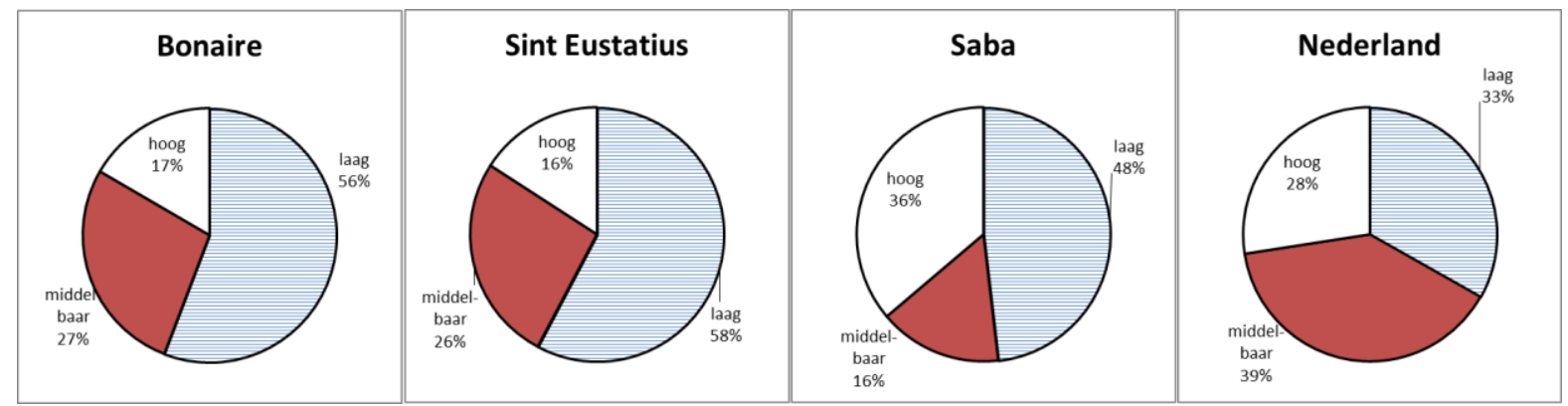

Bron: CBS (Statline)

In figuur 2.2 is het geboorteland van de inwoners per eiland weergegeven. De meeste inwoners zijn op de Nederlandse Antillen of Aruba geboren. Voor Bonaire is dat meer dan de helft, maar voor Sint Eustatius en Saba minder dan de helft. Een groot deel van de bevolking komt uit Latijns-Amerika, ca. een vijfde op Bonaire en Saba, tegenover een bijna derde op Sint Eustatius. Op de laatste twee eilanden is de bevolking die in Nederland is geboren een hele kleine minderheid. Op Sint Eustatius en Saba vormen de mensen die geboren zijn in Noord-Amerika de op twee na grootste bevolkingsgroep. Op Bonaire is dat met $14 \%$ de bevolking die in Nederland is geboren. Wat betreft de eerste nationaliteit van de inwoners is er minder variatie, en duiden de cijfers in veel sterkere mate op de binding met Nederland. Ruim $80 \%$ van de bevolking op Bonaire heeft Nederland als eerste nationaliteit. Voor Sint Eustatius en Saba is dat respectievelijk ruim $60 \%$ en ruim $50 \%$. Het percentage inwoners met een nationaliteit van de VS of Canada is vooral op Sint Eustatius en Saba groot, namelijk $13 \%$ respectievelijk $29 \%$.

Figuur 2.2

De bevolking naar geboorteland voor de BES-eilanden (15-65 jr.), 1 januari 2013

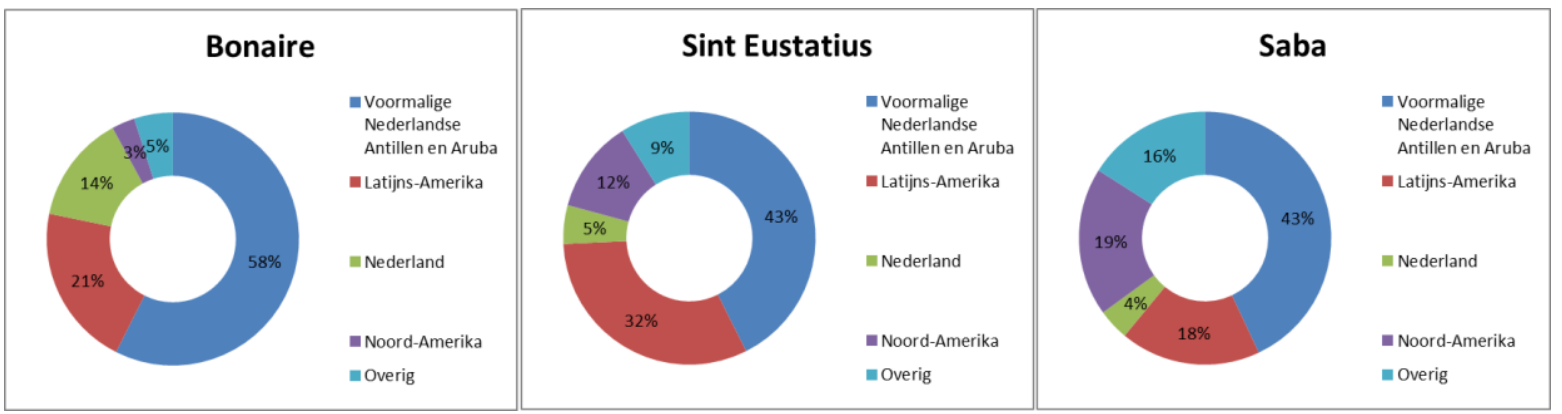

Bron: Statistics Netherlands (2013)

Uit de cijfers van het CBS (Statistics Nederlands, 2013) komt een beeld naar voren van een jaarlijks relatief omvangrijke immigratie (10\% op Bonaire; $8 \%$ op Sint Eustatius en $22 \%$ op Saba) en emigratie, welke ongeveer de helft van de immigratie is. Voor een belangrijk deel zijn dat arbeidsmigranten, onder wie relatief veel mannen. Daarnaast is er bijvoorbeeld enige immigratie vanwege Amerikaanse 
studenten die aan de School of Medicine op Saba studeren. Het is te verwachten dat zich ook onder onderwijsgevenden een omvangrijke instroom en uitstroom vanwege migratie voordoet.

Uit figuur 2.3 blijkt dat de arbeidsparticipatie op Caribisch Nederland vergelijkbaar is met Europees Nederland. Ongeveer zeven op de tien inwoners Caribisch Nederland is werkzaam.

Figuur 2.3

Netto arbeidsparticipatie (15- tot 65-jr.) in Caribisch Nederland, 2012

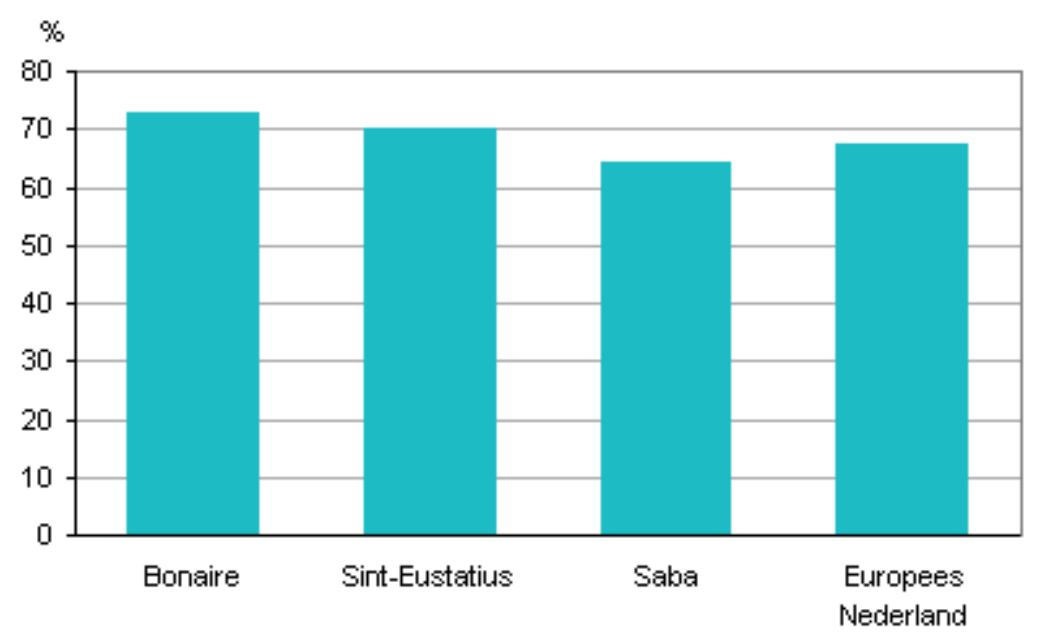

Bron: CBS

Figuur 2.4 laat zien dat de BES-eilanden wat betreft werkloosheid zelfs iets beter scoren dan Europees Nederland. Op Bonaire bedroeg de werkloosheid 6,2\%. Dat komt neer op ongeveer 560 werklozen. Het is iets lager dan in Europees Nederland, waar in 2012 ongeveer 6,4\% van de beroepsbevolking werkloos was. $\mathrm{Na} 2012$ is de werkloosheid gestegen in Europees Nederland en waarschijnlijk ook op de BES-eilanden.

Figuur 2.4

Werkloosheid (15- tot 65-jr.) in Caribisch en Europees Nederland, 2012

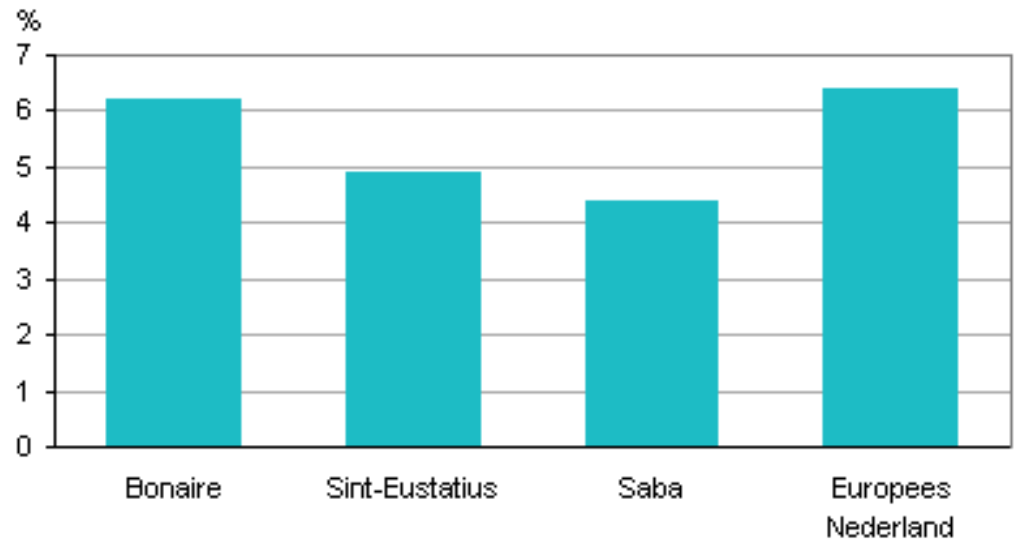

Bron: CBS

In een recent rapport van Ecorys (2013) wordt er per BES-eiland ingegaan op het onderwijssysteem en de aansluiting met de arbeidsmarkt. Het blijkt dat een aanzienlijk deel van de jongeren kiest voor een opleiding aan een onderwijsinstelling buiten de BES-eilanden, vooral in Curaçao, Aruba en Nederland. Verder wordt er gewezen op het relatief grote aandeel leerlingen dat voortijdig het 
onderwijs verlaat zonder diploma ('drop-outs'), en op de niet-optimale of onvoldoende aansluiting tussen onderwijs en arbeidsmarkt in zowel kwantitatieve als kwalitatieve zin. De arbeidsmarktfricties die zich voordoen zijn specifiek voor elk eiland.

\section{$2.6 \quad$ Sociale problematiek}

Op de BES-eilanden is er sprake van een groot armoedeprobleem, vooral onder de Zuid-Amerikaanse migranten en de oorspronkelijke bevolking. Dit is gerelateerd aan de relatief grote groep van laagopgeleiden in de bevolking (zie figuur 2.1). De Inspectie van het Onderwijs (2014) rapporteert dat naar schatting zeker de helft van de bevolking qua inkomen op of iets boven de armoedegrens leeft. Mede door de armoede is er een grote sociale problematiek onder kinderen (verwaarlozing, verslaving, misbruik, etc.), die uiteraard ook van invloed is op de zorg en het onderwijs voor deze kinderen. Er zijn veel kinderen met leer- en ontwikkelingsproblemen die extra zorg en intensieve begeleiding in het onderwijs nodig hebben.

Door de nieuwe onderwijswetgeving is er echter geen speciaal onderwijs meer, terwijl er geen of te weinig deskundigheid beschikbaar is op de scholen om leerlingen speciale begeleiding op maat te bieden. Hierdoor loopt de basiskwaliteit van de leerlingenzorg in het onderwijs gevaar. Ook is er onvoldoende ondersteuning door de Expertisecentra Onderwijs Zorg. Bovendien wordt er nog weinig effectief samengewerkt met goed functionerende instellingen binnen de kinderopvang, de gehandicaptenzorg en de sociale werkvoorziening, en met ketenpartners als de Centra voor Jeugd en Gezin, de Jeugdzorg en de Voogdijraad. Hierdoor staan veel onderwijsinstellingen en expertisecentra er alleen voor bij de ondersteuning van leerlingen die extra zorg nodig hebben.

\section{$2.7 \quad$ Taalproblematiek}

De voertaal op Saba en Sint Eustatius is Engels, dat echter afwijkt van het standaard Engels (Brits of Noord-Amerikaans). Daarentegen is Papiamentu de voertaal op Bonaire. Het onderwijs op Saba is geheel Engelstalig, zowel in de basisschool als in het voortgezet onderwijs. Ook wordt er in het Engels geëxamineerd. Nederlands wordt hier gegeven als vreemde taal. Over het algemeen horen of spreken leerlingen op Caribisch Nederland buiten school nauwelijks Nederlands.

Op Bonaire en Sint Eustatius wordt het (beroeps)onderwijs in de praktijk gegeven in twee talen: het Nederlands en het Papiamentu of Engels. Het lesmateriaal, de instructie en de examinering zijn echter officieel in het Nederlands. Toch moeten leraren vaak overgaan op Papiamentu of Engels om hun uitleg begrijpelijk te maken. In Sociale Kanstrajecten en op niveau 1 in het mbo wordt wel Papiamentu of Engels gesproken als instructietaal, en wordt hierin tevens geëxamineerd.

Voor Sint Eustatius worden er door Faraclas et al. (2013) aanbevelingen gedaan om de taalproblematiek op Sint Eustatius op te lossen. Als meest wenselijke optie wordt voorgesteld het gebruik van het Engels als instructietaal en het Nederlands als vreemde taal, in combinatie met de examenstructuur van de Caribbean Examination Council (CXC); voor het beroepsonderwijs een aangepast model. Dit is in wezen dezelfde opzet als op Saba. Wat betreft Sint Eustatius lijkt er nu te worden gekozen voor het Engels als instructietaal. Daartoe zullen voorstellen voor een transitietraject worden gedaan (Ministerie van OCW, 2014), waarbij Saba als voorbeeld dient. 


\section{De arbeidsmarkt voor leraren}

\subsection{Model personeelsbehoefte}

Het bepalen van de personeelsbehoefte van scholen en het maken van lerarenprognoses is onder normale omstandigheden al ingewikkeld (Cörvers, 2014, blz. 9 e.v.). Er is sprake van vraag en aanbod op zowel de externe arbeidsmarkt, i.e. buiten de beslissingsbevoegdheid van scholen, als op de interne arbeidsmarkt, i.e. onder invloed van keuzes van scholen. Belangrijkste determinant voor de vraag naar leraren is uiteraard het aantal leerlingen per onderwijssector en de bijbehorende bekostiging: hoe meer leerlingen, hoe meer leraren benodigd zijn. Een toename of afname van het totale aantal leerlingen leidt op korte of langere termijn tot een verandering in de omvang van het lerarenbestand. Een tweede vraagfactor is de uittrede van leraren en de doorstroom naar andere functies. Een derde factor is de verblijfsduur van jongeren in het onderwijs. Tot slot is er het beleid en de regelgeving van de overheid met elementen als het door de overheid ter beschikking gestelde budget, de nagestreefde klassengrootte, de lessentabel, bevoegdheden, etc.

Het aanbod aan leraren op de externe arbeidsmarkt bestaat uit degenen die leraar zijn, de werkloze en uitgestroomde leraren, en de afgestudeerden van lerarenopleidingen. Dit aanbod wordt mede bepaald door primaire (vooral beloning) en secundaire arbeidsvoorwaarden (vrije dagen, recht op deeltijdarbeid etc.). Daarnaast kan ook de status van het beroep bijdragen aan de aantrekkingskracht om te kiezen voor een lerarenopleiding.

Om iets meer te zeggen over de behoefte aan leraren op Caribisch Nederland wordt in de volgende paragrafen ingezoomd op twee onderdelen die van belang zijn voor de arbeidsvraag naar leraren:

- Het aantal leraren in relatie tot het aantal kinderen. De toename van de werkgelegenheid bepaalt de uitbreidingsvraag naar leraren;

- De vervangingsbehoefte aan leraren. De vervangingsvraag naar leraren wordt bepaald door de uitstroom van leraren uit het onderwijs vanwege pensionering, een andere baan buiten het onderwijs en vooral emigratie.

De som van de uitbreidingsvraag en de vervangingsvraag bepaalt het aantal baanopeningen. De baanopeningen kunnen worden gemeten door de vacatures die openvallen. Het concept van vacatures en de meting van het aantal vacatures is echter niet eenduidig, en hoeft zeker niet overeen te komen met het aantal baanopeningen zoals hierboven weergegeven.

Vacatures ontstaan door de wisselwerking tussen vraag en aanbod op de onderwijsarbeidsmarkt. Een eerste ingang om zicht te krijgen op de personeelsbehoeften is te kijken naar het aantal en de soort vacatures. Op verzoek van het ministerie voor OCW brengt het ITS op basis van een kwartaalmeting de zogeheten arbeidsmarktbarometer uit. De BES-eilanden lopen hier in mee voor het po en vo (Wester, 2013). Het probleem is evenwel de grote non-respons aldaar. Van de 13 po-scholen reageerden er drie, en van de zes vo-scholen reageerde slechts de helft. Volgens de opgaven van de scholen die wel ontvangen zijn was er eind 2012 sprake van een beperkt aantal vacatures. In het primair onderwijs waren er geen vacatures voor onderwijzend personeel en twee vacatures voor ondersteunend personeel. In het voortgezet onderwijs stonden er eind 2012 voor het onderwijzend personeel twee vacatures open, voor het ondersteunend personeel slechts één. Een dergelijke lage 
respons, met wellicht een grote selectiviteit in de respons, zegt weinig over de dynamiek op de onderwijsarbeidsmarkt op het moment van waarneming. Er kunnen op basis hiervan geen uitspraken gedaan worden over de huidige, laat staan de toekomstige personeelsbehoeften in het onderwijs.

\subsection{Bevolkingsomvang, leerlingenaantallen en scholen}

Uit tabel 3.1 blijkt dat de bevolking van de BES-eilanden gestaag groeit. Jaarlijks bedraagt de groei zo'n 4\%. De groei van het aantal jongeren houdt hier evenwel geen gelijke tred mee. De toename van de bevolking zit dus vooral in de hogere leeftijdsklassen. In dit opzicht lijkt er ook op Caribisch Nederland sprake te zijn van vergrijzing. Voor de prognose van de behoefte aan leraren mogen dus niet de gemiddelde groeicijfers van de bevolking worden aangenomen.

Tabel 3.1

Groei van de bevolking van Caribisch Nederland, absoluut en relatief (2010=100) op 1 januari, $2010-2014$

\begin{tabular}{|c|c|c|c|c|c|}
\hline Bevolking naar leeftijd & 2010 & 2011 & 2012 & 2013 & 2014 \\
\hline Aantal totaal & 20.882 & 21.345 & 22.303 & 23.296 & 24.279 \\
\hline Indexcijfer totaal & 100 & 102 & 107 & 112 & 116 \\
\hline Indexcijfer 0 tot 5 jr. & 100 & 100 & 101 & 103 & 109 \\
\hline Indexcijfer 5 tot $10 \mathrm{jr}$. & 100 & 99 & 101 & 99 & 103 \\
\hline Indexcijfer 10 tot $15 \mathrm{jr}$. & 100 & 99 & 103 & 105 & 108 \\
\hline Indexcijfer 15 tot $20 \mathrm{jr}$. & 100 & 102 & 101 & 102 & 104 \\
\hline
\end{tabular}

Bron: CBS (2014)

Het aantal scholen op de BES-eilanden is gerelateerd aan het inwoneraantal en derhalve gering. leder eiland kent een school voor het voortgezet onderwijs die tegelijkertijd een mbo-afdeling omvat. Tabel 3.2 is gebaseerd op gegevens van Dienst Uitvoering Onderwijs (DUO) en het Centraal Bureau voor de Statistiek (CBS). Het blijkt dat het aantal leerlingen in het bekostigde onderwijs over de drie eilanden is gestegen met ca. 400 leerlingen van 3.833 in schooljaar 2009/10 naar 4.237 in schooljaar 2013/14. Deze groei komt voor ca. driekwart door de toename van het mbo-onderwijs, vooral op Bonaire, en voor het overige door de toename van het vo op Bonaire. Het po en vo op Sint Eustatius en Saba zijn enigszins gekrompen gedurende de laatste jaren. 
Tabel 3.2

Aantal leerlingen en aantal door de overheid bekostigde scholen

\begin{tabular}{|c|c|c|c|c|}
\hline & Bonaire & Sint Eustatius & Saba & Totaal \\
\hline PO 2009 / 2010 & 1.678 & 377 & 160 & 2.215 \\
\hline PO 2010 / 2011 & 1.597 & 345 & 155 & 2.097 \\
\hline PO 2011 / 2012 & 1.650 & 356 & 147 & 2.153 \\
\hline PO 2012 / 2013 & 1.632 & 365 & 154 & 2.151 \\
\hline PO 2013 / 2014 & 1.687 & 340 & 150 & 2.177 \\
\hline VO 2009 / 2010 & 1.037 & 267 & 105 & 1.409 \\
\hline VO 2010 / 2011 & 1.078 & 265 & 99 & 1.442 \\
\hline VO 2011 / 2012 & 1.039 & 251 & 94 & 1.384 \\
\hline VO 2012 / 2013 & 1.102 & 244 & 89 & 1.435 \\
\hline VO 2013 / 2014 & 1.145 & 253 & 97 & 1.495 \\
\hline MBO 2009 / 2010 & 209 & - & - & 209 \\
\hline MBO 2010 / 2011 & 216 & - & - & 216 \\
\hline MBO 2011 / 2012 & 340 & - & - & 340 \\
\hline MBO 2012 / 2013 & 388 & 31 & 12 & 431 \\
\hline MBO 2013 / 2014 & 505 & 39 & 21 & 565 \\
\hline Totaal 2009/10 & 2.924 & 644 & 265 & 3.833 \\
\hline Totaal 2010/11 & 2.891 & 610 & 254 & 3.755 \\
\hline Totaal 2011/12 & 3.029 & 607 & 241 & 3.877 \\
\hline Totaal 2012/13 & 3.122 & 640 & 255 & 4.017 \\
\hline Totaal 2013/14 & 3.337 & 632 & 268 & 4.237 \\
\hline Scholen PO 2012 & 7 & 4 & 1 & 12 \\
\hline Scholen VO 2012* & 1 & 1 & 1 & 3 \\
\hline Scholen MBO 2012* & (1) & (1) & (1) & (3) \\
\hline
\end{tabular}

* De VO-scholen per eiland herbergen ook een MBO-afdeling.

Bron: CBS (Statline)

Het rapport van de Inspectie van het Onderwijs (2014) vermeldt tevens dat er op elk van de drie eilanden een Sociaal Kanstraject Jongeren wordt aangeboden. Deze onderwijsvorm valt ook onder het bekostigd onderwijs. Per 1 oktober 2012 waren hiervoor op Bonaire 62 deelnemers, en op Sint Eustatius en Saba elk vijf deelnemers.

Al groeit het leerlingenaantal van Bonaire enigszins, er is sprake van krimp voor het po en vo op Sint Eustatius en Saba. Het gaat echter om kleine aantallen die in de loop der tijd aan relatief grote fluctuaties onderhevig kunnen zijn. Verder kan een rol spelen dat jongeren deels in het particuliere of niet-bekostigde onderwijs instromen, of wellicht buiten de BES-eilanden onderwijs gaan volgen.

Voor Bonaire zijn er naast de in paragraaf 2.3 genoemde instellingen de volgende andere instellingen:

- Een private basisschool;

- Eén van de basisscholen valt onder bijzonder onderwijs; in de Nederlandse terminologie heet dat speciaal onderwijs;

- Een Fundashon FORMA, dat wil zeggen een centrum voor volwasseneneducatie;

- Een Expertisecentrum Onderwijs Zorg (EOZ), dat is een kenniscentrum voor leerlingen die vragen om specifieke zorg. Ook de opvang van voortijdig schoolverlaters kan hieronder vallen. 
Voor Sint Eustatius zijn dat de volgende onderwijsinstellingen:

- Een private basisschool;

- Een EOZ (Expertisecentrum Onderwijs Zorg).

Volgens informatie van het ROA CN (Raad Onderwijs Arbeidsmarkt Caribisch Nederland) zijn er recentelijk twee particuliere opleidingen opgericht, die (nu nog) geen erkende opleidingen aanbieden, maar die wel gediplomeerde leerkrachten werven. Dit zijn het Onderwijs Instituut Caribisch Nederland (OICN) en Kennis Opent Deuren (KOD). Er is op basis van de nu beschikbare gegevens geen zicht op de ontwikkeling van het aantal leerlingen en het aantal benodigde leraren in de hierboven genoemde (niet-bekostigde) instellingen.

\subsection{Uitbreidings- en vervangingsvraag naar leraren}

De uitbreidings- en vervangingsvraag naar leraren kan worden bepaald aan de hand van de werkgelegenheidsomvang en de uitstroom van leraren. Uit gegevens van de Inspectie van het Onderwijs (2014) kunnen de werkgelegenheid en de uitstroom worden afgeleid. Het blijkt dat er bij aanvang van het schooljaar 2010/2011 en 2013/2014 respectievelijk 302 en 371 leraren in dienst waren bij onderwijsinstellingen van het po en vo/mbo op Caribisch Nederland. In tabel 3.3 zijn deze gegevens verbijzonderd naar po en vo/mbo, waarbij tevens de uit- en instroom is weergegeven.

Tabel 3.3

Aantal leerkrachten, in- en uitstroom op de BES-eilanden, po, vo/mbo, totaal, 2010-2013

\begin{tabular}{|c|c|c|c|c|}
\hline & 2010 & $\begin{array}{r}\text { vertrokken sinds } \\
10-10-10 \\
\end{array}$ & $\begin{array}{r}\text { aangesteld na } \\
10-10-10 \\
\end{array}$ & 2013 \\
\hline \multicolumn{5}{|l|}{ po } \\
\hline Aantal leerkrachten & 145 & 52 & 61 & 154 \\
\hline Als percentage van 2010 & $100 \%$ & $(36 \%)$ & $42 \%$ & $106 \%$ \\
\hline \multicolumn{5}{|l|}{$\mathrm{vo} / \mathrm{mbo}$} \\
\hline Aantal leerkrachten & 157 & 69 & 127 & 217 \\
\hline Als percentage van 2010 & $100 \%$ & $(44 \%)$ & $81 \%$ & $138 \%$ \\
\hline \multicolumn{5}{|l|}{ Totaal } \\
\hline Aantal leerkrachten & 302 & 121 & 188 & 371 \\
\hline Als percentage van 2010 & $100 \%$ & $(40 \%)$ & $62 \%$ & $123 \%$ \\
\hline
\end{tabular}

Bron: Opgave door de scholen, aangeleverd aan de Inspectie van het Onderwijs door Rijksdienst Caribisch Nederland (RCN, afd. Onderwijs)

Als alle leraren na hun opleiding 40 jaar blijven werken zonder van werkgever te wisselen, en de leraren gelijkmatig naar leeftijd verdeeld zijn, is er een vervangingsbehoefte van $2,5 \%$ per jaar. Voor de BES-eilanden is dit 2,5\% van 371, ofwel ca. negen nieuwe leraren per jaar. Uit tabel 3.3 blijkt echter dat $40 \%$ van de leraren in 2010 in de drie daaropvolgende jaren (tot aanvang schooljaar 2013/2014) is uitgestroomd, dat wil zeggen een gemiddeld jaarlijks uitstroompercentage van $13,3 \%$. Dit is veel hoger dan het eerder genoemde percentage $2,5 \%$, omdat er veel leraren uitstromen vanwege een baan elders op de BES-eilanden of vanwege emigratie. De berekende uitstroom staat gelijk aan een vervangingsvraag van gemiddeld 40 leraren per jaar. Daarnaast is de werkgelegenheid 
toegenomen met gemiddeld 7,6\% per jaar ${ }^{2}$, waarschijnlijk mede door de toename van het aantal leerlingen. Dit impliceert een uitbreidingsvraag van gemiddeld 23 leraren per jaar. In totaal bedroeg het aantal baanopeningen dus gemiddeld jaarlijks 63 leraren voor de BES-eilanden over de drie schooljaren tussen 2010 en 2013.

Het aantal baanopeningen van 63 leraren per jaar kan als richtsnoer dienen voor de komende periode, maar is met de nodige onzekerheid omgeven. Ten eerste is een dergelijke naïeve benadering niet gebaseerd op een bevolkingsprognose of een prognose van het aantal leerlingen voor de komende jaren. Deze prognoses zijn ook lastig te maken omdat veelal sterk fluctuerende migrantenstromen een grote invloed hebben op de bevolkingsomvang en het aantal leerlingen op de eilanden. Ten tweede is de werkelijke vervangingsvraag op eilandenniveau wellicht overschat, omdat een deel van de uitstroom mogelijk gaat werken bij een andere school op de BES-eilanden. Het wisselen van school wordt hier meegeteld als vervangingsvraag op eilandenniveau. Als bijvoorbeeld een leraar basisonderwijs bij een andere basisschool op één van de BES-eilanden aan de slag gaat omdat op die school een leraar naar Nederland is geëmigreerd, ontstaat er per saldo op het niveau van Caribisch Nederland slechts voor één en niet voor twee leraren vervangingsvraag. ${ }^{3}$

Het getal van 63 leraren per jaar kan worden uitgesplitst naar po en vo/mbo. Met dezelfde methode en met dezelfde onzekerheden kan worden vastgesteld dat het aantal baanopeningen voor het po gemiddeld jaarlijks 20 leraren bedraagt, en voor het vo/mbo 43 leraren. Verdere uitsplitsingen kunnen worden gemaakt voor het po en vo/mbo op de afzonderlijke eilanden, maar door de kleine aantallen is dit niet zo zinvol. Wel worden in tabel 3.4 de aantallen leraren bij aanvang schooljaar 2013/2014 weergegeven voor de onderwijstypes op de drie BES-eilanden. Het is hier nog van belang te vermelden dat alle tellingen door de scholen zelf zijn gebeurd, en dat er geen verificatie heeft plaatsgevonden door de Inspectie van het Onderwijs.

Tabel 3.4

Aantal leraren op de BES-eilanden in het po en vo/mbo, aanvang schooljaar 2013/2014

\begin{tabular}{|l|r|r|r|}
\hline & po & vo/mbo & totaal \\
\hline Bonaire & 105 & 149 & 254 \\
\hline Saba & 16 & 24 & 40 \\
\hline Sint Eustatius & 33 & 44 & 77 \\
\hline Totaal & 154 & 217 & 371 \\
\hline
\end{tabular}

Bron: Opgave door de scholen, aangeleverd aan de Inspectie van het Onderwijs door Rijksdienst Caribisch Nederland (RCN, afd. Onderwijs)

Bij het richtgetal van 63 baanopeningen per jaar voor de BES-eilanden kan er niet vanuit worden gegaan dat de baanopeningen zich helemaal evenredig met de werkgelegenheid van leraren over de eilanden verdelen. In de voorbij periode is de uitbreidingsvraag van gemiddeld 20 leraren per jaar waarschijnlijk vooral in het vo en mbo op Bonaire ontstaan, als we kijken naar de groei van het aantal leerlingen op de drie eilanden (zie tabel 3.2). De uitbreidingsvraag was echter slechts ca. een derde van het totale aantal baanopeningen. De vervangingsvraag van ca. 40 leraren per jaar is moeilijk te voorspellen doordat de migratiepatronen op de arbeidsmarkt voor leraren niet bekend en onzeker

2. Er wordt bij de berekening van de jaargemiddeldes telkens uitgegaan van het rekenkundige in plaats van het meetkundige gemiddelde.

3. Het is overigens niet duidelijk hoe er geteld is als de nieuwe school onder dezelfde werkgever (i.e. hetzelfde bestuur) valt. Maar verreweg de meeste scholen zijn éénpitters (Inspectie van het Onderwijs, 2014). 
zijn. Maar Bonaire zal ook in de vervangingsvraag naar verwachting verreweg het grootste aandeel hebben op de BES-eilanden. Als hier wel de werkgelegenheid wordt aangehouden om de vervangingsvraag te verdelen heeft Bonaire naar schatting ruim twee derde van de totale vervangingsvraag op de BES-eilanden. Dit is gelijk aan ongeveer 30 leraren per jaar. Gegeven de ruim 60 baanopeningen op de BES-eilanden zou Bonaire derhalve grofweg 50 nieuwe leraren gemiddeld per jaar moeten aanstellen om de baanopeningen in te vullen, en Saba en Sint Eustatius ongeveer 10 leraren. Dit onder een hele reeks van aannames, waaronder de veronderstelling dat de dynamiek van in- en uitstroom de komende jaren niet sterkt verandert ten opzichte van de periode 2010-2013.

\subsection{Herkomst en bevoegdheid van leraren}

Het onderwijs op de BES-eilanden heeft te maken kleine leerlingenaantallen, versnippering en kleinschaligheid van het onderwijs, en een diverse sociaal-culturele achtergrond van leerlingen wat betreft onder meer herkomst, taal, en levensstandaard. Hoewel het speciaal en specialistisch onderwijs er nog onderontwikkeld is, wordt het primair en secundair onderwijs er vrij breed aangeboden, op een vergelijkbare wijze als in Europees Nederland, inclusief de vele denominaties in het po en de verschillende niveaus en richtingen (profielen, crebo-opleidingen) in het vo en mbo. Het potentieel om leraren te werven is daarbij heel beperkt door de kleine beroepsbevolking op de BESeilanden, die voor een groot deel laagopgeleid is, en ook qua cultuur, herkomst en taal erg divers is (zie hoofdstuk 2). Volgens de Inspectie van het Onderwijs (2014) zijn de leraren op de BES-eilanden afkomstig uit Caribisch Nederland, Europees Nederland, de CAS-eilanden en uit diverse andere landen in de regio, zoals Guyana, Jamaica en Suriname. Zoals eerder opgemerkt hebben veel leerlingen in de praktijk Papiamentu of Engels nodig om geïnstrueerd te worden, zelfs als Nederlands de officiële instructie- en examentaal is. Dit vraagt om bekwaamheden van leraren die vaak niet in de bevoegdheidseisen zijn terug te zien.

Op de BES-eilanden zijn er geen zelfstandige lerarenopleidingen. Het ligt daarom voor de hand dat er leraren worden geworven in Nederland, op de CAS-eilanden (Curaçao, Aruba Sint Maarten), waar wel lerarenopleidingen zijn, en breder in de Caribische regio. De leraren hebben dus zeer uiteenlopende opleidingsachtergronden. Doordat de BES-eilanden vallen onder de Nederlandse regelgeving, betekent dat er met extra aandacht moet worden gekeken of de verschillende internationale diploma's van lerarenopleidingen erkend worden door de NVAO. Hoewel er nu nog een overgangsregeling geldt voor de bevoegdheden van leraren, moeten zij op termijn beschikken over een Nederlandse of een daaraan gelijkgestelde bevoegdheid.

In figuur 3.1 wordt de herkomst van het diploma weergegeven voor leraren van het po en vo/mbo op de BES-eilanden per 10-10-10. In het basisonderwijs had in 2010 bijna de helft van de leraren met een diploma uit de Nederlandse Antillen of Aruba. Daarnaast was er nog een vijfde met een Nederlands diploma, van wie de meesten afkomstig zijn uit Caribisch Nederland. Ook heeft een groot deel van de leraren een diploma uit Suriname. Deze leraren geven opvallend vaak les op Sint Eustatius. Op Saba is de lerarenpopulatie erg divers, met leraren uit voornamelijk de Nederlandse Antillen en Aruba, Nederland en de VS, terwijl op Bonaire een grote meerderheid van de leraren een diploma heeft van de Nederlandse Antillen en Aruba. 


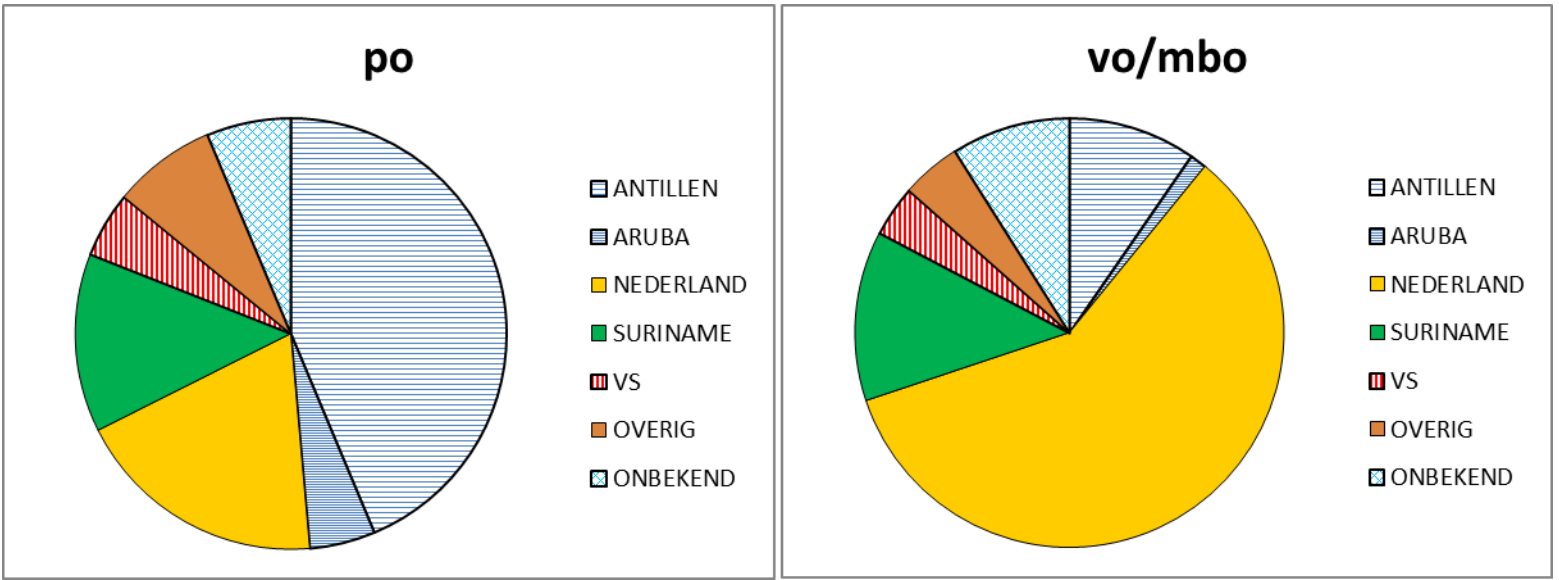

Bron: Inspectie van het Onderwijs

In het vo en mbo hebben veel leraren een diploma van Europees-Nederlandse bodem. Volgens de Inspectie van het Onderwijs (2014) is een grote meerderheid van hen ook afkomstig uit Nederland. Dit geldt voor ruim twee derde van de diploma's op Bonaire. De overige diploma's zijn behaald op de Antillen of in Suriname. Vooral op Saba en in mindere mate op Sint Eustatius is het aandeel leraren met een Europees Nederlands diploma veel kleiner. Op Saba is de herkomst van de diploma's zeer divers, op Sint Eustatius hebben leraren vrijwel uitsluitend een diploma uit Nederland, de VS of Suriname.

Uit het rapport van de Inspectie van het Onderwijs (2014) blijkt dat het percentage bevoegde leraren op de BES-eilanden tussen 10-10-10 en bij aanvang van het schooljaar 2013/14 nauwelijks is gestegen, namelijk van $77 \%$ naar $78 \%$. Weliswaar is het percentage onbevoegden (inclusief de onbevoegden in opleiding) afgenomen, maar dat komt doordat het percentage onbekend is gestegen. Het is derhalve moeilijk om een significante verbetering van de situatie gedurende de voorbije transitiefase hard te maken. Desondanks beweert de Inspectie van het Onderwijs (2014) in haar rapportage dat er gedurende deze jaren een vertrek van onbevoegden heeft plaatsgevonden, tegenover een instroom van bevoegden en zittende leraren die sinds 10-10-10 hun bevoegdheid hebben behaald.

In figuur 3.2 wordt de verdeling van de bevoegdheid van leraren in het po en vo/mbo voor het totaal van de BES-eilanden weergegeven per 1 september 2013. In het po is het percentage bevoegdheid beduidend groter dan in het vo/mbo. Maar in het vo/mbo zijn in tegenstelling tot het po veel meer leraren in opleiding voor hun bevoegdheid. Als zij allen hun diploma halen komt het percentage leraren dat bevoegd is vrijwel op het niveau van het po. Daarnaast is er in het vo/mbo een groter percentage leraren waarvoor de bevoegdheid (nog) niet duidelijk is. Dit heeft waarschijnlijk ook te maken met de verscheidenheid aan opleidingen in het vo/mbo en de diversiteit van herkomst van de diploma's onder de betreffende leraren. 
Figuur 3.2

Verdeling van leraren naar bevoegdheid in het po en vo/mbo op de BES-eilanden, 1 september 2013

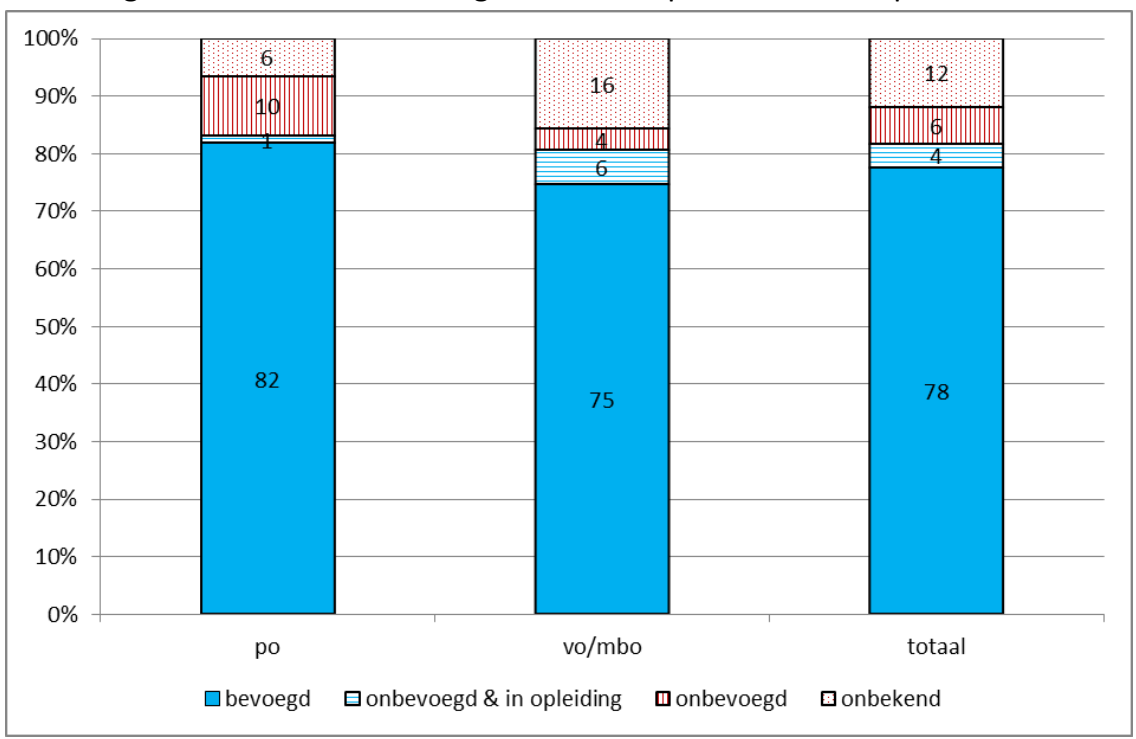

Bron: Inspectie van het Onderwijs

In het vo in Europees Nederland wordt ca. $75 \%$ van de lessen gegeven door bevoegden. Dit percentage is nog wat lager voor het mbo (Berndsen en Van Leenen, 2013). In vergelijking met Europees Nederland lijkt de situatie in het vo en mbo op de BES-eilanden nog mee te vallen (hoewel niet helemaal vergelijkbaar als gevolg van het percenteren op lessen c.q. leraren). Dat de percentages bevoegdheid voor het vo en mbo in Caribisch en Europees Nederland min of meer overeenkomen heeft er misschien mee te maken dat een groot deel van de leraren in het vo/mbo op de BES-eilanden een diploma heeft gehaald in Europees Nederland (zie figuur 3.1). Het ministerie van OCW (2013a) heeft overigens in de Lerarenagenda 2013-2020 als doelstelling voor Nederland geformuleerd dat binnen enkele jaren alle leraren bevoegd moeten zijn voor het vak waarin ze lesgeven.

Uit figuur 3.3 blijkt dat het met het percentage bevoegdheid onder de leraren op Bonaire beter is gesteld dan op Sint Eustatius en Saba. ${ }^{4}$ Niet alleen is het percentage bevoegde leraren op Sint Eustatius en vooral Saba kleiner, ook waren er per 1 september 2013 geen leraren in opleiding, in tegenstelling tot Bonaire. Op Sint Eustatius en Saba vraagt vooral het hoge percentage onbevoegden in het po extra aandacht.

4. Het gaat hier om het totaal van po en vo/mbo per eiland. Vanwege de kleine aantallen wordt er niet verder gedifferentieerd naar de verschillende onderwijsvormen per eiland. 
Figuur 3.3

Verdeling van leraren naar bevoegdheid op Bonaire, Sint Eustatius en Saba, 1 september 2013

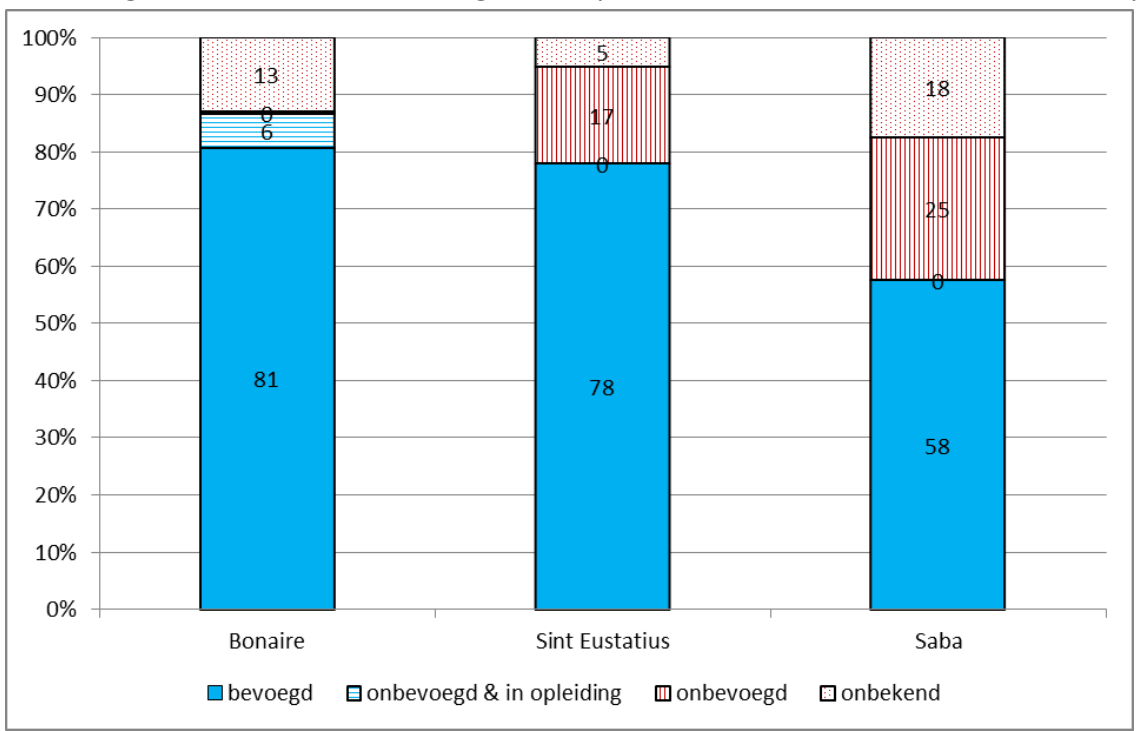

Bron: Inspectie van het Onderwijs

Tot slot moet er bij de figuren 3.2 en 3.3 de kanttekening worden geplaatst dat de bevoegdheidssituatie, evenals veel andere kenmerken van de lerarenpopulatie op de BES-eilanden, aanzienlijk kan zijn veranderd tussen september 2013 en het nieuwe schooljaar 2014/15, vanwege de jaarlijks grote uit- en instroom van leraren op de verschillende scholen. Volgens tabel 3.3 was immers de gemiddeld jaarlijkse uitstroom van leraren bijna $15 \%$ in de periode $2010-2013$, en de gemiddeld jaarlijkse instroom ruim $20 \%$.

\subsection{Opleidingsbehoefte onder leraren}

Om een idee te krijgen van de opleidingsbehoefte onder leraren kunnen er verschillende benaderingen worden gekozen. Daarbij kan het helpen om onderscheid te maken tussen bevoegdheden en bekwaamheden. Bevoegden zijn gekoppeld aan door de NVAO erkende diploma's. Bekwaamheden staan feitelijk los van deze diploma's, hoewel verwacht mag worden dat bevoegde leraren bekwamer zijn dan onbevoegde leraren. Bekwaamheid kan worden gekoppeld aan de diverse basis- en complexe vaardigheden van leraren zoals deze worden gemonitord door de Inspectie van het Onderwijs (2014a).

Wat betreft de bevoegdheden is er veel te doen rondom het opleiden van leraren op de BESeilanden. In een evaluatie van de Onderwijsagenda door het ministerie van OCW (2013) is een inventarisatie opgemaakt van het lerarenbestand op de BES-eilanden en een assessment uitgevoerd onder 95 leraren die on- of onderbevoegd waren. Dit aantal komt min of meer overeen met de ca. 100 leraren die per 10-10-10 volgens gegevens van de Inspectie van het Onderwijs, welke in paragraaf 3.4 zijn gebruikt, niet bevoegd waren of van wie de bevoegdheid onbekend was. Van de 95 leraren bleken er bij nader onderzoek 13 alsnog bevoegd te zijn, en kwamen er 58 leraren in aanmerking om te starten met een scholingstraject om de bevoegdheid te halen. De opleiding van deze leraren gebeurt in principe via het opleidingsprogramma van Maestro Kompas in samenwerking met door de Hogeschool Utrecht/Faculteit Educatie (HU/FE) en de Open Universiteit (OU), uit additioneel ter beschikking gestelde middelen van het ministerie van OCW. Uit de stand van zaken 
zoals weergegeven door Maestro Kompas, blijkt dat er vanaf 2012 tot augustus 2014 ca. 40 leraren in opleiding waren om hun bevoegdheid te halen. De overige leraren hebben ofwel dispensatie aangevraagd, of hebben het onderwijs verlaten dan wel zich teruggetrokken om een andere reden. Uit de gegevens van de Inspectie van het Onderwijs blijkt dat er per 1 september 201339 van de 371 leraren onbevoegd waren, onder wie 15 leraren in opleiding. Voor 44 leraren was de bevoegdheid op dat moment niet bekend. Door de verschillende momenten van bevraging en de grote dynamiek van in- en uitstroom laten deze cijfers zich echter niet eenvoudig vergelijken met de opgave van Maestro Kompas.

Een andere benadering voor het bepalen van de opleidingsbehoefte in verband met de bevoegdheid kan plaatsvinden op basis van de in- en uitstroomgegevens in paragraaf 3.4. In tabel 3.5 zijn de verschillende veronderstellingen en uitkomsten in een matrix weergegeven. Een basisveronderstelling bij de tabel is dat het aantal benodigde nieuwe leerkrachten ten gevolge van onder meer de groei van het aantal leerlingen en de uitstroom van zittende leraren, in de komende periode niet wezenlijk afwijkt van het gemiddelde in de periode 2010-2013. Er zal dan de komende jaren weer een instroom van 63 leraren per jaar nodig zijn om de baanopeningen die ontstaan door de uitbreidings- en vervangingsvraag in te vullen. Bovendien wordt verondersteld dat $20 \%$ van de nieuwe leraren on- of onderbevoegd is, ongeveer gelijk aan het percentage van onbevoegden in het zittende lerarenkorps als de categorie onbekend wordt meegerekend (zie figuur 3.2). Onder deze veronderstellingen is het aantal onbevoegde leraren voor bijscholing gelijk aan 13, i.e. $20 \%$ van 63 . Het percentage onbevoegden onder de nieuwe leraren kan echter ook toenemen. Dit is te voorzien als het door grotere schaarste op de arbeidsmarkt voor leraren in de Caribische regio en/of in Nederland moeilijker wordt om bevoegde leraren aan te trekken. Onder de veronderstelling dat het percentage onbevoegde leraren in de instroom toeneemt tot $30 \%$, neemt het aantal onbevoegde leraren dat in aanmerking komt voor bijscholing toe tot 19 per jaar.

Om het minimale aantal nieuwe leraren te berekenen dat in aanmerking komt voor bijscholing wordt verondersteld dat er geen uitbreidingsvraag is en dat scholen op de BES-eilanden erin slagen om een groter percentage bevoegde leraren aan te trekken, waardoor het percentage onbevoegde leraren in de instroom daalt tot bijvoorbeeld $10 \%$. Uitbreidingsvraag kan uitblijven als er geen groei van het leerlingenaantal is. Met alleen vervangingsvraag ontstaan er 40 baanopeningen per jaar. Het jaarlijkse aantal onbevoegde leraren dat bijgeschoold moet worden om de bevoegdheid te halen, is dan gelijk aan vier, i.e. $10 \%$ van 40 leraren.

\section{Tabel 3.5}

Verwachte instroom van onbevoegde leraren die in aanmerking komen voor bijscholing, aantal per jaar onder verschillende aannames, gebaseerd op de periode 2010-2013

\begin{tabular}{|l|r|r|}
\hline $\begin{array}{r}\text { Uitbreidingsvraag } \\
\text { Onbevoegde instroom }\end{array}$ & geen & historisch \\
\hline $\mathbf{1 0 \%}$ & 4 & 6 \\
\hline $\mathbf{2 0 \%}$ & 8 & 13 \\
\hline $\mathbf{3 0 \%}$ & 12 & 19 \\
\hline
\end{tabular}

Bron: ROA, op basis van gegevens van de Inspectie van het Onderwijs

Als de achterstand van de voorbij jaren is ingehaald ten aanzien van het opleiden van onbevoegde leraren, zullen er naar schatting elk jaar ca. 13 leraren opgeleid moeten worden om hun bevoegdheid te halen. Dat kan echter per jaar fluctueren van minder dan 5 tot bijna 20, afhankelijk van onder 
meer de kwaliteit van de instroom van leraren (i.e. percentage onbevoegden) en de groei van het leerlingenaantal (i.e. de uitbreidingsvraag). Op basis van de verdeling van de onbevoegde leraren per 1 september 2013 kan voorts worden verwacht dat het aantal leraren dat opgeleid moet worden ongeveer gelijk verdeeld is over enerzijds het po en anderzijds het vo/mbo.

Wat betreft de bekwaamheden is er, zoals in paragraaf 2 opgemerkt, een gebrek aan speciaal en specialistisch onderwijs op de BES-eilanden. Dit kan in combinatie met de kleinschaligheid van het onderwijs (i.e. combinatieklassen), de armoedeproblematiek, het lage opleidingsniveau van ouders, en de taalproblematiek een rol spelen voor zowel leerlingen als leraren in het reguliere onderwijs. Als men op de BES-eilanden wil voldoen aan de Nederlandse onderwijsstandaarden vraagt dit waarschijnlijk vaak meer complexe vaardigheden van leraren dan in de Europees-Nederlandse situatie.

De Inspectie van het Onderwijs (2014, blz. 41) concludeert echter dat met betrekking tot de onderwijssituatie op de BES-eilanden "de systematiek van kwaliteitszorg en de professionele cultuur zeer verschilt tussen de verschillende vestigingen en in veel gevallen te wensen overlaat" en "De personeelsbestanden zijn zeer heterogeen wat betreft cultuur en professionele achtergrond, wat de onderwijskundige aansturing compliceert." Dit betekent dat er genoeg aandachtpunten zijn voor het investeren in de bekwaamheden van leraren op de BES-eilanden. Het gaat hier om een inschatting van de cursussen en trainingen die leraren nu en in de toekomst na hun initiële opleiding zouden willen/moeten volgen om hun kennis- en vaardigheidsniveau op peil te houden. Hierbij dient ook rekening te worden gehouden met de (mogelijke toekomstige) ambities en richtlijnen van het ministerie van OCW ten aanzien van bevoegdheden en bekwaamheden, bijv. coaching van leraren en de recente masterdoelstellingen voor leraren in Nederland.

Het tegemoet komen aan de opleidingsbehoeften van leraren kan op verschillende manieren worden aangepakt:

- De overheid kan bepaalde speerpunten benoemen zoals passend onderwijs, of werken met referentieniveaus voor lezen en rekenen, en de markt speelt vervolgens daarop in;

- de Inspectie van het Onderwijs kan op bepaalde lacunes wijzen die vervolgens worden aangepakt;

- De scholen kunnen zelf actiepunten voor professionalisering van leraren benoemen;

- De docenten kunnen zelf de behoeften aangeven. Uit onderzoek rondom Leraar24 is echter bekend dat leraren op de vraag naar hun scholingsbehoeften een eindeloze rij items aangeven, met bijna evenveel onderwerpen als er respondenten zijn (Claessen, 2010 en Claessen en Vinken, 2010). 


\section{Randvoorwaarden en opties voor digitale onderwijsinfrastructuur}

\subsection{Randvoorwaarden}

Wat betreft de randvoorwaarden voor een digitale onderwijsinfrastructuur binnen het samenwerkingsverband van de UniCarib partners, is de vraag welke rol een virtuele campus (als duurzame onderwijsinfrastructuur) kan spelen voor Caribisch Nederland en de hele Caribische regio. Zoals in paragraaf 1 al is gesteld, dient een toekomstige virtuele campus een model voor blended online onderwijs te ondersteunen. Alleen door de juiste randvoorwaarden te vervullen en richtlijnen te bieden, leidt blended online onderwijs tot efficiënt en effectief leren. Het gaat hierbij om randvoorwaarden op de volgende punten.

Beschikbaarheid. De beschikbaarheid - capaciteit en betrouwbaarheid - van internet in de regio is vooralsnog beperkt. Dit betekent dat synchrone ('real time', directe) communicatie via het internet niet vanzelfsprekend gegarandeerd is. Met name videoconferencing/virtual classroom sessies leveren geregeld problemen op. Alternatieven hiervoor, zoals audioconferencing over internet (behoeft minder capaciteit), teleconferencing (via het telefoonnetwerk), en vooraf opgenomen en als video verspreide lecture sessies dienen dan ook als serieus onderdeel van de toekomstige infrastructuur ingezet te worden.

Toegankelijkheid. Zelfs wanneer internet beschikbaar is, zal niet voor alle studenten (en mogelijk ook docenten) de toegankelijkheid op ieder moment en op iedere plek vanzelfsprekend zijn. Het inrichten van lokale voorzieningen waar studenten internettoegang hebben (studiecentra waar ook andere ondersteunende diensten beschikbaar kunnen zijn), en het actief stimuleren van persoonlijke internetabonnementen en het gebruik van mobile devices, zoals tablets, zorgen ervoor dat de toegankelijkheid vergroot wordt.

Docentvaardigheden. Het ontwikkelen en effectief inzetten van blended online onderwijs vergt nieuwe kennis, vaardigheden en attitudes van docenten. Het ontwikkelen van online (multimedia) zelfstudie-materialen kost veel tijd waarbij de vraag naar de 'return on investment' dan ook steeds serieus gesteld moet worden. (Her)gebruik van bestaande leermaterialen, waaronder zeer zeker ook boeken en readers, maar ook bestaande online materialen van derden (van partnerinstellingen, Youtube, Slideshare etc.) heeft waar mogelijk dan ook de voorkeur boven het zelf ontwikkelen. Desalniettemin zullen docenten getraind moeten worden in het (her)gebruik van bestaande, en het zelf ontwikkelen van nieuwe, multimedia lesmaterialen; in het inrichten van een elektronische leeromgeving; in het voorbereiden en geven van online onderwijs; en in het effectief begeleiden van studenten 'op afstand'. Naast een initiële opleidings/trainingsinspanning vergt dit op langere termijn ook permanente professionalisering en ondersteuning.

Studentvaardigheden. In blended online onderwijs wordt het nodige gevraagd van de studenten. Een belangrijk deel bestaat uit zelfstudie. Dit vergt zelfsturing en een actieve studiehouding. In een context waar docentgestuurd onderwijs de norm is, met een zwak ontwikkelde 'leescultuur', en waar de studie in constante 'concurrentie' is met professionele en persoonlijke prioriteiten, zal het blended online onderwijs volgens een strak schema ingericht moeten worden, met frequent 
ingebouwde controle-activiteiten om de voortgang van de studenten te bewaken en waar nodig bij te sturen. Naast zelfstudie zullen ook alternatieven zoals online lectures - vooraf opgenomen of 'live' via webconferencing/virtual classroom sessies - ingezet moeten worden voor kennisoverdracht en vraag-antwoordsessies. De face-to-face bijeenkomsten dienen vooral gereserveerd te worden voor sociale interactie en leeractiviteiten waarbij directe feedback van de docent een duidelijk toegevoegde waarde heeft. Tussenvormen waarmee door UniCarib partners al ervaring is opgedaan, zoals de 'rondreizende docent ' en een virtuele klas met ondersteuning door een lokale tutor, passen goed in dit model.

Management/governance. Maar al te vaak leidt online onderwijs tot onpersoonlijk, inferieur, en te duur onderwijs. Het is de taak van het management om a) richtlijnen en randvoorwaarden te bieden en te bewaken, welke leiden tot kwalitatief goed blended online onderwijs, en b) te voorkomen dat het online onderwijs enkel een 'add-on' bovenop het reguliere klassikale onderwijs blijft (en daarmee een kostenpost zonder toegevoegde waarde).

\subsection{Status van UniCarib partners bij blended online onderwijs}

De huidige UniCarib partners hebben reeds in mindere of meerdere mate ervaring opgedaan met online blended onderwijs, en hun toekomstige ambities op dit vlak geformuleerd. Daartoe worden de verschillende opleidingen genoemd die de UniCarib partners aanbieden, en de ervaringen met een digitiale onderwijsinfrastructuur.

\section{Instituto Pedagogico Arubano}

Het Instituto Pedagogico Arubano (IPA, http://www.ipa.aw) biedt de volgende opleidingen aan:

- Opleiding Primair Onderwijs, voor de leeftijdscategorieën 4-8 en 6-12 jaar.

- Pedagogisch-Didactisch Getuigschrift (PDG).

- Opleiding Basis Speciaal- en Voortgezet Speciaal Onderwijs voor zittende leerkrachten van het Speciaal Onderwijs.

- Verkort traject 6-12 opleiding voor leerkrachten van de specialisatie 4-8 en andere leerkrachten die de bevoegdheid 6-12 erbij willen halen.

- Opleiding voor CT (Consumptieve Technieken) voor het voortgezet onderwijs, alleen voor zittende leerkrachten.

IPA heeft reeds enige ervaring opgedaan met het ontwikkelen van eigen modules in Moodle, en in het gebruik van $\mathrm{HUbl}^{5}$ in het kader van het Maestro Kompas project. Een deel van de medewerkers heeft deelgenomen aan trainingen op het gebied van Moodle, het zelf blended online onderwijs maken, en het maken van multimediaal lesmateriaal.

Verder heeft IPA onlangs het studentvolgsysteem Schoolfit geïnstalleerd en is IPTA bezig met de inrichting en het overzetten van de informatie en processen van alle opleidingen, vakken, studenten en docenten.

5. Ontwikkeld door Mentorix voor de Hogeschool Utrecht op basis van het Drupal-platform. Zie http://www.mentorix.eu/\#!technology/mainPage en http://www.mentorix.eu/\#!hogeschool-utrecht/ceww . 


\section{Universiteit van Aruba}

De Universiteit van Aruba (UA, http://www.ua.aw) biedt via haar vier faculteiten de volgende programma's aan:

- Faculty of Law: Bachelor Degree in Aruban Law; Master Degree in Aruban Law.

- Faculty of Accounting, Finance \& Marketing: Bachelor Accounting \& Finance (HBO Bedrijfseconomie); Bachelor Marketing (HBO-Commerciële Economie).

- Faculty of Hospitality, Tourism Management \& International Studies: Bachelor in Hospitality and Tourism Management (B.Sc.); Master in Tourism and International Business (MBA).

- Faculty of Arts \& Science: Bachelor in Organization, Governance and Management; Bachelor in Social Work \& Development; Lerarenopleiding wiskunde.

Daarnaast biedt het Center for Lifelong Learning workshops, seminars, maatwerk-trainingen, korte (zomer)cursussen, en postacademische cursussen.

Docenten hebben in mindere en meerdere mate ervaring opgedaan met het werken in EDU 2.0 (een cloud-gebaseerde ELO), en binnen de lerarenopleiding wiskunde wordt met Moodle gewerkt. Voor het beheer van studentgegevens wordt OSIRIS $^{6}$ gebruikt. Toegang tot de online voorzieningen is geregeld via een studentenportaal.

In de naaste toekomst wil UA haar huidige onderwijs gebaseerd op traditionele hoorcolleges meer richting (inter)actieve onderwijsvormen ontwikkelen, zoals de flipped classroom $^{7}$ en blended learning. Daarnaast is internationalisering een belangrijk thema in de UA-strategie 2014-2020: een consortium van onderwijsaanbieders moet een oplossing bieden voor de zogenoemde 'eilandenproblematiek' door gezamenlijk voldoende 'doelgroepomvang' en daarop gericht onderwijsaanbod te creëren. UniCarib is een eerste stap in deze strategie. Een belangrijke doelgroep bestaat uit (toekomstige) onderwijzers.

\section{Universiteit van Curaçao}

De Universiteit van Curacao (UoC, http://www.uoc.cw) biedt via haar vijf faculteiten de volgende programma's aan:

- Faculty of Law: Bachelor in Law; Master in Law.

- Faculty of Engineering: Bachelor in Electrical Systems; Bachelor in Industrial Technology; Bachelor in Civil Engineering; Bachelor in Architecture; Bachelor in Information and Communication. Technology; Techno Master in Business Administration (Techno-MBA).

- Faculty of Social Sciences and Economics: HBO Bachelor Business Administration; HBO Bachelor Fiscal Law \& Economics; WO Bachelor Accounting \& Controlling; WO Bachelor Business \& Economics; MSc in Accounting; MSc in Business Management; Executive Master in Financial Management.

- Faculty of Social and Behavioral Sciences: Bachelor Social Work; Master Social Work.

6. OSIRIS is een studentinformatiesysteem, speciaal ontwikkeld voor het Nederlands hoger onderwijs, zie http://www.osiris4u.nl/nl/

7. 'Flipped' refereert hier aan het omdraaien van de leeractiviteiten in traditioneel onderwijs, waar kennis wordt overgedragen in de klas en vervolgens met huiswerkactiviteiten wordt geoefend. In het 'flipped classroom' model vindt kennisverwerving vooral plaats door zelfstudie op basis van door de docent geselecteerde en/of ontwikkelde multimedia leermaterialen, terwijl de klassikale bijeenkomsten vooral worden gebruikt om te oefenen en feedback te geven. 
- Faculty of General Arts (Algemene Faculteit): 1ste en 2de graads lerarenopleidingen in Papiamento, Nederlands, Engels en Spaans; Master Special Educational Needs (SEN); Lerarenopleiding Funderend Onderwijs (LOFO) met een nevenvestiging op Bonaire.

De Algemene Faculteit (AF) heeft reeds ervaring opgebouwd met het gebruik van Blackboard Collaborate (een videoconferencing/virtual classroom tool) in het kader van taalonderwijs aan studenten op Bonaire en Aruba. Ook is Collaborate gebruikt om docenten uit Europa online gastcolleges te laten verzorgen. Op dit moment worden de 'lessons learned' verwerkt, welke ook nuttige input kunnen vormen voor de discussie rondom de UniCarib infrastructuur.

Onlangs heeft Universiteit van Curaçao haar Blackboard licentie vernieuwd, en zijn cursussen voor medewerkers georganiseerd. Enkele docenten van de AF hebben in het kader van Maestro Kompas met HUbl gewerkt, en voor de Master Special Educational Needs (SEN) wordt op basis van Sharepoint een bronnenbestand aangelegd en verder uitgewerkt tot elektronische leeromgeving. Naast de AF is ook UoC's afdeling Library Research Services (LRS) betrokken bij het initiatief 'Building the Dutch Caribbean Digital Platform', op basis van software ontwikkeld in samenwerking met de University of Florida. ${ }^{8}$

De AF wil als volgende stap het gebruik van Collaborate uitbreiden naar de master Special Educational Needs, de cursus Pedagogisch Didactische Voorbereiding, en wellicht de Bacheloropleidingen. Vervolgens wordt het blended maken van het huidige materiaal als optie gezien.

De komende tijd wil de AF in de context van UniCarib en met behulp van Collaborate alle tien haar programma's deels blended online aan gaan bieden. Een instituutsoverstijgende virtuele leeromgeving is hierbij mede leidraad. Voorwaarde daarbij is niet alleen uitwisseling van expertise, maar ook van de nodige hardware en menskracht (technische ondersteuning).

\section{Universiteit van Sint Maarten}

De Universiteit van St. Maarten (USM, http://www.usmonline.net) biedt de volgende opleidingen aan:

- Associate of Arts in Business: Management Concentration.

- Associate of Arts in Business: Accounting Concentration.

- Associate of Applied Science in Business Information Management.

- Associate of Applied Science in Hospitality and Tourism Management.

- Associate of Arts in General Liberal Arts: General Studies.

- Associate of Arts in General Liberal Arts: Mathematics \& Science Concentration.

- Bachelor of Arts in Education.

- Teacher Certificate Program.

- Reading Certificate Program.

- Special Education Certificate Program.

- International Business and Management Studies.

8. Zie http://ufdcimages.uflib.ufl.edu/AA/00/02/42/12/00002/Binder1.pdf en http://www.dloc.com/dloc1/faq. 
Status en ambities op het vlak van blended online onderwijs waren op het moment van het afsluiten van dit vooronderzoek nog niet door USM aangeleverd.

\subsection{Componenten van een digitale infrastructuur}

Al naar gelang de ambities zal een digitale infrastructuur voor de UniCarib partners geheel of deels uit de volgende componenten bestaan:

1. Voorlichting en werving waar potentiële studenten online opleidingsinformatie vinden en de mogelijkheid hebben zich bij de opleiding kenbaar te maken/aan te melden.

2. Online aanbieden van (multimedia) leermaterialen door de opleiding/docent aan studenten zoals teksten, presentaties, video's, audio-fragmenten etc. die door studenten (zelfstandig) online bestudeerd kunnen worden en/of gedownload kunnen worden naar de eigen computer of tablet.

3. Asynchrone communicatie en samenwerking (niet in 'real time') tussen studenten en docenten en tussen studenten onderling. Door middel van e-mail, online forums, wikis, blogs etc. Wordt gebruikt voor het verspreiden van nieuwsberichten door de docent; het stellen van vragen aan docent en medestudenten; insturen en van feedback voorzien van opdrachten; sociale interactie ('muurkrant') tussen studenten; etc. waarbij het niet noodzakelijk is direct een reactie te ontvangen.

4. Synchrone communicatie en samenwerking ('real time' communicatie), door middel van chat, teleconferencing, videoconferencing. Wordt gebruikt voor vraag-antwoord sessies tussen studenten en docent; overleg tussen studenten over een gezamenlijke opdracht; verzorgen van online 'live' lessen door de docent; sociale interactie ('cybercafé') tussen studenten; etc. waarbij directe dialoog noodzakelijk is.

5. (Zelf)toetsen en quizzen voor het (zelf) bepalen van de voortgang (formatieve toetsing) en/en het afnemen van formele toetsen (summatieve toetsing).

6. Administratie en beheer van student- en docentgegevens, voortgangsbewaking, cijferadministratie, etc.

7. Regelen en bewaken van toegang en rechten tot bovenstaande componenten voor belangstellenden, studenten, docenten en alumni. Relevant hier is of er al dan niet gewerkt wordt met single sign on (centraal inloggen op alle systemen met één gebruikersnaam en wachtwoord).

Bij de individuele UniCarib partners zijn al verscheidene van de genoemde systemen operationeel. Tabel 4.1 vat samen welke componenten door welke systemen (kunnen) worden afgedekt. ${ }^{9}$ Voor de Universiteit van Sint Maarten en voor de component rechten en toegangsbeheer zijn er op het moment van het afsluiten van dit vooronderzoek geen gegevens bekend.

9. Van sommige geïmplementeerde systemen wordt in de praktijk nog maar een klein deel van de functionaliteit benut. 
Tabel 4.1

Stand van zaken ten aanzien van de componenten van de digitale infrastructuur bij de opleidingen van de UniCarib partners

\begin{tabular}{|c|c|c|c|c|}
\hline & IPA & $U A$ & UoC & USM \\
\hline $\begin{array}{l}\text { 1. Voorlichting en } \\
\text { werving }\end{array}$ & website & website & website & website \\
\hline $\begin{array}{l}\text { 2. Aanbieden van } \\
\text { online } \\
\text { leermaterialen }\end{array}$ & $\begin{array}{l}\text { Moodle } \\
\text { HUbl }\end{array}$ & $\begin{array}{l}\text { EDU2.0 } \\
\text { Moodle }\end{array}$ & $\begin{array}{l}\text { Blackboard Learn+ } \\
\text { Sharepoint } \\
\text { HUbl }\end{array}$ & $?$ \\
\hline $\begin{array}{l}\text { 3. Asynchrone } \\
\text { communicatie }\end{array}$ & $\begin{array}{l}\text { Moodle } \\
\text { HUbl } \\
\text { E-mail }\end{array}$ & $\begin{array}{l}\text { EDU2.0 } \\
\text { Moodle } \\
\text { E-mail }\end{array}$ & $\begin{array}{l}\text { Blackboard Learn+ } \\
\text { E-mail }\end{array}$ & ? \\
\hline $\begin{array}{l}\text { 4. Synchrone } \\
\text { communicatie }\end{array}$ & Skype? & $?$ & $\begin{array}{l}\text { Blackboard Colla- } \\
\text { borate }\end{array}$ & $?$ \\
\hline 5. Toetsen/quizzen & $\begin{array}{l}\text { Moodle } \\
\text { HUbl }\end{array}$ & $\begin{array}{l}\text { EDU2.0 } \\
\text { Moodle }\end{array}$ & Blackboard Learn+ & $?$ \\
\hline 6. Administratie & Schoolfit & OSIRIS & $?$ & $?$ \\
\hline $\begin{array}{l}\text { 7. Rechten-en } \\
\text { toegangsbeheer }\end{array}$ & $?$ & $?$ & $?$ & $?$ \\
\hline
\end{tabular}

Bron: $\mathrm{OU}^{10}$

Bij het definiëren van een UniCarib digitale infrastructuur helpt het als duidelijk is uit welke soorten infrastructuren gekozen kan worden (paragraaf 4.4), en wat de opties zijn tussen 'centraal' en 'decentraal', dat wil zeggen Unicarib componenten versus componenten bij ieder van de partnerinstellingen (paragraaf 4.5).

\subsection{Dominante infrastructuurmodellen}

Op dit moment zien we vijf dominante 'smaken' of modellen van digitale infrastructuren binnen het onderwijs. Deze worden hieronder besproken.

Leermanagementsysteem (LMS). Voorbeelden hiervan zijn Blackboard, Moodle en EDU2.0. Bij een leermanagement-systeem (LMS) zijn alle componenten uit de vorige subparagraaf geïntegreerd in één systeem, of kunnen ze (bijvoorbeeld in het geval van een virtual classroom, zie hieronder) daarin eenvoudig geïntegreerd worden ('plug in'). Dit is het favoriete model bij de meeste onderwijsinstellingen en bedrijven die online onderwijs/training aanbieden. Voordelen zijn de integratie van alle benodigde functies binnen één omgeving, en het centrale beheer. Steeds vaker (ook in geval van Blackboard en Moodle) is het LMS niet meer 'lokaal' binnen de eigen instelling op een server geïnstalleerd, maar bij een externe provider 'in de cloud'. Hierbij wordt het complexe technisch beheer dus uitbesteed, maar blijft het functioneel beheer in handen van de instelling. Als nadelen van het LMS-model worden vooral de complexiteit ('stijle leercurve') en het gebrek aan flexibiliteit genoemd.

Virtuele klas/virtual classroom. Dit zijn in de kern web-conferencing tools met daaraan toegevoegd functies zoals het vertonen van presentaties; een online whiteboard waarop geschreven en getekend kan worden; chat; de mogelijkheid om 'polls' te houden; etc. De docent bepaalt veelal welke van

10. Meer gedetailleerde informatie over het gebruik van de verschillende componenten bij de partnerinstellingen, en over de plannen en ambities van deze instellingen, is beschikbaar bij Erik Kluijfhout. 
deze functies beschikbaar zijn voor de studenten die aan de sessie deelnemen. Virtual classrooms worden vooral gebruikt voor online lectures, voor vraag-en-antwoord sessies, en om als groepje studenten samen 'op afstand' aan een opdracht te werken. De sessies kunnen meestal ook opgenomen worden om na de sessie online als video beschikbaar gesteld te worden voor studenten die de sessie nog eens willen bekijken of er niet bij konden zijn. Enkele bekende voorbeelden van virtual classroom tools zijn Adobe Connect, Big Blue Button, Big Marker, Blackboard Collaborate (voorheen Elluminate), en WebEx. Veelal zijn er speciale voorzieningen getroffen om de virtual classroom eenvoudig te integreren in een LMS. Ook gratis tools als Skype (van Microsoft) en Hangout (van Google) bieden veel van deze functies en worden dan ook breed ingezet in het onderwijs. ${ }^{11}$ Deze tools doen een groot beroep op de capaciteit en betrouwbaarheid van de internetverbinding.

Personal desktop. In plaats van een ELO met daarbinnen alle geïntegreerde componenten kunnen instellingen en individuele docenten ook gebruik maken van de vele - vaak gratis - beschikbare losse web-diensten die er voor de meeste van bovenstaande componenten beschikbaar zijn (Youtube, webmail, Slideshare, Issuu, Soundcloud, etc.). Omdat de docent hier zelf de componenten kan kiezen wordt dit wel aangeduid als het personal desktop model. Voordelen van dit model zijn de flexibiliteit, de mogelijkheid tot (kosteloos) experimenteren met verschillende tools, en het feit dat de docent 'in control' is. Dit zijn tegelijkertijd de nadelen: vrijwel niet centraal te beheren en reguleren, en de docent en studenten dienen zeer computer-en web-vaardig te zijn.

Zelfbouw of assemblage. Een tussenvorm is het als instelling zelf (laten) ontwikkelen van een LMS, veelal op basis van bestaande componenten. Dit zelfbouw- of assemblage model ligt ten grondslag aan systemen zoals $\mathrm{HUbl}$ van de Hogeschool Utrecht ${ }^{12}$ en OpenU van de Open Universiteit ${ }^{13}$. Voordelen zijn de mogelijkheid maatwerk te realiseren, en 'ownership'. Nadelen van dit model zijn de hoge kosten en de slechte ervaringen wat betreft sustainability.

Google/Microsoft. Een andere tussenvorm wordt geboden door softwaregiganten als Google en Microsoft die een deel van hun producten als geïntegreerde onderwijsomgeving (vrijwel) gratis beschikbaar stellen voor het onderwijs. Google doet dat met hun Google Apps for Education ${ }^{14}$ en Microsoft met Office 365 for Education. ${ }^{15}$ Dit model lijkt wat op de personal desktop-model (gebruik van allemaal losse componenten/applicaties), waarbij de applicaties waaruit de docent kiest beperkt blijven tot die van één leverancier met als bijkomend voordeel dat het toegangsbeheer bij de instelling ligt. Een ander voordeel is dat veel van de gebruikte tools bij studenten en docenten bekend zullen zijn (denk aan Gmail, Googledocs en Youtube van Google; en Outlook, Skype en Word van Microsoft). Nadeel is dat het toch gaat om vrij los van elkaar staande componenten, waarmee niet zo eenvoudig een coherente digitale leeromgeving in te richten is.

\footnotetext{
11. Een aantal van deze tools zijn in het kader van de samenwerking tussen Nederland (Open Universiteit) en Aruba (IPA) getest. Informatie hierover is beschikbaar bij Erik Kluijfhout.

12. Gebouwd op basis van het bestaande open source systeem Drupal door het Deense bedrijf Mentorix.

13. Gebouwd op basis van het bestaande open source systeem Liferay in eigen beheer.

14. Zie: http://www.google.nl/intx/nl/enterprise/apps/education/ .

15. Zie: http://office.microsoft.com/nl-nl/microsoft-office-365-voor-hoger-onderwijs-FX102918415.aspx.
} 
UniCarib is te beschouwen als een consortium dat in een nader te bepalen onderwijsinfrastructuur leraren wil opleiden of bijscholen. Een onderwijsconsortium dat onderling (aan elkaars studenten) cursussen wil aanbieden en gezamenlijk een externe markt wil bedienen, kan kiezen voor één van de volgende opties voor een technische infrastructuur (LMS en/of virtuele klas):

1. Eén systeem, één instantie. In dit model gebruiken alle partners hetzelfde systeem dat onder één licentie gehost wordt door een externe partij, of door één van de partners. Groot voordeel is eenduidigheid voor studenten en medewerkers en, afhankelijk van welk systeem wordt gekozen, een mogelijk prijsvoordeel. Belangrijkste nadeel doet zich voor als één of meerdere partners al werkt met, en gewend is aan een ander systeem en/of daar financiële verplichtingen liggen. Daarnaast lopen de partners die het systeem niet zelf hosten bij een onbetrouwbare internetvoorziening het risico regelmatig afgesloten te zijn van hun systeem. Doordat iedereen met hetzelfde systeem werkt, creëert dit model een flinke afhankelijkheid tussen de partners. Vragen die beantwoord moeten worden: Wie voert het functioneel beheer (inrichting, look en feel, etc.); wie is 'eigenaar', en wie is beheerder van de student-accounts in het systeem; hoe is de ondersteuning naar studenten en docenten geregeld; hoe worden personele inzet en kosten verdeeld en verrekend.

2. Eén systeem, ieder een eigen instantie. In dit model gebruiken alle partners hetzelfde 'merk' maar iedere partner heeft daarbij wel een eigen versie (instantie) met een eigen licentie, en beslist zelf over de inrichting en beheer hiervan. Voordelen zijn de eenduidigheid voor studenten en docenten; het feit dat cursussen tussen de verschillende partner-versies eenvoudig uitwisselbaar zijn; dat men een beroep kan doen op elkaars expertise; en dat iedere partner toch 'in control' is van het eigen systeem. Nadeel is dat partners die al een ander systeem in gebruik hebben dit moeten vervangen of anders twee systemen naast elkaar moeten beheren. Het risico bestaat dat na verloop van tijd de verschillende versies zodanig uiteen gaan lopen dat de voordelen niet meer te realiseren zijn. Ook in dit model zullen de partners daarom toch basale afspraken moeten maken, met name over versiebeheer.

3. Eén consortiumsysteem, eigen instellingssystemen. In dit model behouden de verschillende partners hun eigen LMS en/of virtuele klas, maar daarnaast wordt er één systeem gekozen waarmee het consortium gezamenlijke cursussen ontwikkelt en aanbiedt. Voordeel is dat dit model een compromis biedt voor een situatie waar veel onderwijs-consortia-in-oprichting zich in bevinden. Er zijn echter ook een aantal nadelen: dubbele licentiekosten; dubbele expertise nodig; voor bestaande cursussen biedt het geen oplossing voor de onderlinge uitwisselbaarheid. Indien het geselecteerde consortiumsysteem reeds door één of meerdere partners gebruikt wordt, gelden voor deze partners de nadelen vanzelfsprekend niet.

4. Geen gezamenlijk systeem. Hierbij besluiten de consortium-partners (voorlopig) geen gezamenlijk systeem te kiezen. Om zich bij dit model toch als consortium te profileren zijn er een aantal opties (in toenemende mate van technische complexiteit):

i. Gezamenlijke online cursuscatalogus. Hierbij richt het consortium een website waarop het consortium het gezamenlijk onderwijsaanbod presenteert. Vanuit de website wordt de bezoeker doorgelinkt naar de website van de aanbiedende partner. Daar kan de kandidaat-student zich vervolgens aanmelden. Na toelating studeert de student in het systeem van de aanbiedende partner. Voordeel van dit systeem is dat het simpel en 
goedkoop te realiseren is en daarmee past in een voorzichtig groeimodel. Nadeel is dat het geen enkele onderwijskundige meerwaarde heeft - het is een marketinginstrument.

ii. Online catalogus en inschrijven. Identiek aan bovenstaande, maar nu kan de kandidaatstudent zich direct op de consortiumwebsite aanmelden. Bijvoorbeeld via een webformulier dat vervolgens bij de betreffende partnerinstelling binnenkomt. $\mathrm{Na}$ toelating studeert de student in het systeem van de aanbiedende partner. Voor- en nadelen zijn identiek aan de hierboven beschreven optie.

iii. Consortiumportaal. Hierbij richt het consortium een zogenoemd 'portaal' in dat studenten directe toegang biedt tot de onderliggende systemen van de partnerinstellingen. In dit model kan een student dus studeren bij verschillende partners, maar hoeft altijd maar op één plek - het portaal - in te loggen om vervolgens in de onderliggende systemen en cursussen terecht te komen. Voordeel is vooral de gebruiksvriendelijkheid voor de student. Nadeel is de technische, en wellicht ook juridische, complexiteit. 


\section{Conclusies}

\subsection{Situatie onderwijs op Caribisch Nederland}

Het ministerie voor OCW (2014a) geeft in een beleidsreactie op het rapport van de Inspectie van het Onderwijs (2014) aan dat er, in overstemming met het inspectierapport, op de BES-eilanden hard is gewerkt om de doelen te halen die gesteld zijn naar aanleiding van de staatkundige hervorming op 10-10-10. Er is grote vooruitgang geboekt, maar nog een lange weg te gaan. De interne kwaliteitszorg en de bestuurskracht zijn niet op orde. Er zijn grote zorgen over specialistische leerlingenzorg op maat. Er zijn taalachterstanden en de invoering van referentieniveaus zoals in Europees Nederland gebruikelijk, stagneert. Bovendien is er veel verloop onder leraren door enerzijds het probleem van ontoereikende detacheringsregelingen die niet toelaten dat men met behoud van rechtspositie werkzaam kan zijn in Caribisch Nederland, en anderzijds scholen die dat ook niet willen omdat dit de verhoudingen wat betreft de rechtspositie binnen het schoolteam zou verstoren.

\subsection{Personeelsbehoefte aan leraren}

Specifiek voor het primair onderwijs (po) geldt dat het aantal leerlingen (acht jaargangen) veel groter is dan in het vo en mbo. Er is bovendien een brede inzetbaarheid van leraren in het po, omdat met een PABO-diploma de afgestudeerden bevoegd zijn voor alle jaargroepen. Niettemin kunnen culturele achtergrond, taalbeheersing buiten het Nederlands, en de denominaties van scholen op de BES-eilanden wel degelijk een belangrijke rol spelen bij de werving van leraren. Leraren met een Antilliaans diploma zijn ver in de meerderheid, en van de leraren in het basisonderwijs die in Nederland hun diploma hebben behaald, zijn de meesten afkomstig uit Caribisch Nederland. Leraren in het po op de BES-eilanden hebben dus sterke Caribische roots. Dit pleit ervoor om in deze regio een opleidingsfaciliteit voor het po te realiseren die door het NVAO erkend wordt.

In het voortgezet onderwijs (vo) en middelbaar beroepsonderwijs (mbo) is het aantal leerlingen klein in relatie tot de onderscheiden bevoegdheden per vak. De behoefte aan leraren is dus gefragmenteerd naar vakken en dat leidt tot een zeer diverse vraag, die per vak en bevoegdheid echter heel klein is. De externe afhankelijkheid in de personeelsvoorziening voor het vo en mbo op de BES-eilanden is heel groot. Bijna twee derde van de leraren in het vo en mbo is in Nederland opgeleid, en de grote meerderheid van hen is ook afkomstig van Europees Nederland. Er is een grote migratiedynamiek onder deel leraren, maar hoe lang ze blijven is vaak onbekend.

\subsection{Opleidingsbehoefte van leraren}

We kunnen inzake de opleidingsbehoefte van leraren op de BES-eilanden de volgende conclusies trekken:

- Ook op de BES-eilanden is er sprake van opleidingsbehoeften na de initiële opleiding van leraren. Er kan onderscheid worden gemaakt tussen bijscholing in bevoegdheden en bekwaamheden;

- Absolute prioriteit heeft het op peil brengen van de bevoegdheden van leraren. Tussen 2010 en 2013 is het percentage leraren op de BES-eilanden met bevoegdheid nauwelijks gestegen (van 77 
naar 78\%). Momenteel zijn er bij Maestro Kompas ongeveer 40 leraren in opleiding waarmee het percentage bevoegden significant kan worden verhoogd;

- Als de achterstand aan onder- en onbevoegden is weggewerkt blijft het opleiden van nieuwe onbevoegde leraren die aan de slag gaan op de BES-eilanden aandacht vergen. Gebaseerd op diverse aannames is de inschatting dat er jaarlijks ongeveer 13 onbevoegde leraren instromen die in aanmerking komen voor bijscholing, maar dit aantal kan jaarlijks fluctueren van minder dan 5 tot bijna 20;

- Een tweede prioriteit is het wegwerken van lacunes en zwakke plekken zoals die door de Inspectie van het Onderwijs worden gesignaleerd. Het oordeel van de Onderwijsinspectie is zwaarwegend voor de beoordeling van de kwaliteit van het onderwijs van een school. Het gaan hier om onvoldoende bekwaamheden door gebrekkige basis- en complexe vaardigheden onder leraren;

- De laagste prioriteit is vooralsnog weggelegd voor na-, her- en bijscholing op basis van de wensen van scholen en individuele leerkrachten;

- Gelet op de specifieke omstandigheden van het onderwijs op de BES-eilanden (geografische afstanden, kleinschaligheid, meertaligheid, etc.), is een toegesneden professionaliseringsbeleid op scholen noodzakelijk.

\subsection{Onderwijsinfrastructuur voor het opleiden en scholen van leraren}

Wat betreft het toekomstige opleidingsmodel voor de personeelsvoorziening van leraren op de BESeilanden zijn er vanwege de grote externe afhankelijkheid verschillende benaderingen.

1. Importmodel: leraren komen feitelijk uit alle windstreken, en vooral uit Nederland. Er is buiten de BES-eilanden voldoende aanbod in bevoegde leraren en in opleidingsfaciliteiten. Er is dus geen personeels- of een opleidingsprobleem, maar veel meer een wervingsprobleem. Voldoende aantrekkelijke arbeidsvoorwaarden kunnen het probleem oplossen.

2. Model van gedeeltelijke zelfvoorziening: leraren zijn in grote mate afkomstig uit de BES-eilanden. Hun opleiding vindt elders plaats, bijvoorbeeld op de CAS-eilanden of in Europees Nederland, maar de bedoeling is dat ze terugkeren naar de BES-eilanden.

3. Model van volledige zelfvoorziening: leraren zijn niet alleen afkomstig van de BES-eilanden, maar hebben ook hun lerarenopleiding genoten op Caribisch Nederland. Deze opleiding zou door de NVAO erkend moeten zijn.

4. Bijscholingsmodel: leraren zijn zoveel als mogelijk afkomstig van de BES-eilanden. Er wordt geaccepteerd dat ze on- of onderbevoegd zijn, waarbij gezorgd voor een adequate bijscholingsstructuur om de lacunes in het lerarenkorps weg te werken. Deze variant is te beschouwen als een tussenvariant van 2 en 3.

\subsection{Virtuele campus en blended online onderwijsmodel}

De invulling van de bovenstaande onderwijsinfrastructuur kan worden gecombineerd met faciliteiten voor 'blended learning'. Blended online onderwijs stelt eisen aan de beschikbaarheid en toegankelijkheid van (internet) technologie, aan de vaardigheden van docenten en studenten hiermee te kunnen werken, en aan de governance. Alleen als in voldoende mate aan de randvoorwaarden is voldaan, leidt blended online onderwijs tot efficiënt en effectief leren. 
Een digitale onderwijsinfrastructuur bestaat uit verschillende componenten: voorlichting en werving, online leermaterialen, asynchrone en synchrone communicatie, toetsen en quizzen, administratie, en het rechten- en toegangsbeheer. Er is voor de UniCarib partners nagegaan welke digitale systemen deze componenten (kunnen) afdekken.

Bij het definiëren van de UniCarib digitale infrastructuur moeten in ieder geval de volgende twee vragen beantwoord worden:

1. Voor welke van de genoemde componenten is een 'eigen' UniCarib versie nodig, en waar moeten die componenten aan voldoen?

2. Welke bestaande componenten blijven bij de individuele partnerinstellingen gehandhaafd, en wat is hun relatie tot de nieuwe UniCarib componenten?

Er bestaan momenteel vijf dominante modellen voor digitale infrastructuren binnen het onderwijs waarmee de componenten kunnen worden vormgegeven, namelijk het Leermanagementsysteem (LMS), de Virtuele klas, de Personal desktop, de Zelfbouw of assemblage, en Google/Microsoft. Voor elk model zijn de voor- en nadelen besproken. Hetzelfde geldt voor de opties voor samenwerking tussen partners in een onderwijsconsortium als UniCarib. Daarbij dient om te worden gegaan met het dilemma 'centraal' (UniCarib componenten) versus 'decentraal' (componenten bij ieder van de partnerinstellingen).

\subsection{Toekomstig onderzoek onderwijsarbeidsmarkt voor Caribisch Nederland}

Wat betreft toekomstige onderzoek is het noodzakelijk om beter zicht te krijgen op de onderwijsarbeidsmarkt op de BES-eilanden en in de Caribische regio. Er kan worden gedacht aan:

- Het nader onderzoeken van de personeelsbestanden bij scholen over leraren en leerlingen, in samenwerking met DUO en de Inspectie van het Onderwijs. Er dient een jaarlijkse inventarisatie plaats te vinden van wie als leraar werkzaam is op de BES-eilanden, met welk diploma en welke bevoegdheid, onder welke arbeidsvoorwaarden, etc.;

- Het verder onderzoeken van beschikbare gegevens bij het UWV en het CBS, bijvoorbeeld wat betreft bijvoorbeeld werkloosheid onder leraren;

- Het opstellen van leerlingenprognoses per school, zodat er beter geanticipeerd kan worden op de personeelsbehoefte van leraren;

- Een enquête onder alle leraren op de BES-eilanden, waarbij niet alleen gevraagd wordt naar persoonskenmerken, dienstverband en vooropleiding, maar ook naar voorkeur, toekomstplannen en motieven. Wie stromen er precies in, en wie uit, en waarom? Dit geeft meer zicht op de kenmerken van de leraren en de omstandigheden en motieven van veranderingen in baan;

- Een enquête onder scholen om te vragen naar de vacaturevervulling, de tevredenheid met het lerarenkorps, het personeelsbeleid, de toekomstverwachtingen ten aanzien van professionalisering, scholing, leerlingenaantallen, etc.;

- Een enquête onder schoolverlaters van havo/vwo en eventueel mbo op Caribisch Nederland om hun interesse voor het beroep van leraar te peilen;

- Een marktonderzoek voor de virtuele campus (Businessmodel Virtual Campus), waarbij het hele palet van tweede en eerstegraads lerarenopleidingen voor po, vo en mbo, voltijd- en 
deeltijdopleidingen, bachelor- en masteropleidingen aan zowel universiteiten als hogescholen, inclusief minoren, van belang kan zijn. Het business model kan in eerste instantie op de BESeilanden gericht zijn (met ondersteuning van het ministerie van OCW), maar zou de potentie moeten hebben/genereren om op de CAS-eilanden en de rest van het Caribisch gebied een goede marktpositie te veroveren. De diploma-erkenning is hierbij een punt van aandacht, evenals de taal waarin het onderwijs moet worden gegeven. 


\section{Literatuur}

Claessen, J. (2010), Nascholingsbehoeften van leraren en aanbod in Leraar24, reeks Leraar24 nr. 6, Open Universiteit, Ruud de Moor Centrum, Heerlen.

Claessen, J. en H. Vinken (2010), Het gebruik van de zoekfunctie op Leraar24, reeks Leraar24 nr. 12, Open Universiteit, Ruud de Moor Centrum, Heerlen.

Cörvers, F. (2014), De arbeidsmarkt voor leraren: theorie, beleid en werkelijkheid, oratie 6 juni, Tilburg University, Prismaprint, Tilburg.

Ecorys (2013), De arbeidsmarkt in Caribisch Nederland 2013, Inclusief aanbevelingen voor beleid, 29 mei, Rotterdam.

Eimers, T. en E. Keppel (2014), De plicht tot verantwoordelijkheid, Nadere inkadering van de zorgplicht doelmatigheid, Kenniscentrum Beroepsonderwijs Arbeidsmarkt, Nijmegen.

Faraclas, N., E.-P. Kester en E. Mijts (2013), Summary of the final report feasibility study into the language of instruction on Sint Eustatius.

Inspectie van het Onderwijs (2008), Het onderwijs op Bonaire, Sint Eustatius en Saba, december, Utrecht.

Inspectie van het Onderwijs (2014), Onderwijsverbetering in Caribisch Nederland, Het onderwijs op Bonaire, Sint Eustatius en Saba, drie jaar na 10 oktober 2010, maart, Utrecht.

Inspectie van het Onderwijs (2014a), De staat van het onderwijs, Onderwijsverslag 2012/2013, Utrecht.

Ministerie van OCW (2011), Onderwijsagenda voor Caribisch Nederland: samen werken aan kwaliteit, Den Haag.

Ministerie van OCW (2013), Evaluatie Onderwijsagenda voor Caribisch Nederland 2012/2013, Brief aan de voorzitter der Staten-Generaal, 29 november 2013, Den Haag.

Ministerie van OCW (2013a), De Lerarenagenda 2013-2020: de leraar maakt het verschil, Den Haag.

Ministerie van OCW (2014), Instructietaal onderwijs Sint Eustatius, Brief aan de voorzitter der StatenGeneraal, 19 juni 2014, Den Haag.

Ministerie voor OCW (2014a), Beleidsreactie inspectierapportage "Onderwijsverbetering in Caribisch Nederland", Rapportage aan Tweede Kamer, 20 juni, Den Haag. 
Onderwijsraad (2013), Grenzen aan kleine scholen, Sterk en pluriform onderwijs in tijden van krimp, februari, Den Haag.

RCN (2014), Bonaire, Sint Eustatius, Saba, Eilandgids Caribisch Nederland, Guia di Isla Hulanda Karibense, Island guide Caribbean Netherlands, Rijksdienst Caribisch Nederland, Addo's Bookstore Bonaire B.V.

Statistics Netherlands (2013), The Caribbean Netherlands in figures 2012, The Hague/Heerlen, Kralendijk.

Wester, M. (2013), Arbeidsmarktbarometer: vacatures op de BES eilanden in het vierde kwartaal, ITS, mei, Radboud Universiteit Nijmegen. 